\title{
A economia da depressão está de volta? *
}

\author{
João Sicsú ${ }^{* *}$
}

\section{Resumo}

O objetivo do artigo é caracterizar a situação econômica brasileira atual e esboçar as linhas gerais de um receituário de recuperação. O Brasil possui nos dias de hoje as principais características das depressões de 1870 e 1930. Naqueles episódios, houve uma queda acentuada do produto, uma elevada taxa de desemprego e uma prolongada insuficiência de demanda. O Brasil vive uma depressão e não apenas uma recessão passageira. O diagnóstico e o receituário para a economia brasileira foram elaborados a partir das ideias e da experiência de John Maynard Keynes durante os anos 1930.

Palavras-chave: Economia brasileira; Depressão; Economia keynesiana.

\begin{abstract}
Has depression economics returned?

The purpose of this article is to characterize the current Brazilian economic situation and outline a prescription for its recovery. Brazil currently encapsulates the main characteristics of the depressions of the 1870s and 1930s. During these events, there was a sharp fall in output, a high unemployment rate and prolonged insufficiency of demand. Brazil faces a depression and not a transitory recession. The diagnosis and the prescription for economic recovery were elaborated from the ideas and experience of J.M. Keynes during the 1930s.
\end{abstract}

Keywords: Brazilian economy; Depression; Keynesian economics.

JEL E32, E23, E12.

Na Grande Depressão, os líderes tinham uma desculpa: ninguém realmente compreendia o que estava acontecendo nem sabia como resolver a situação. Os líderes de hoje não têm essa desculpa. Temos tanto o conhecimento quanto as ferramentas para acabar com esse sofrimento (Krugman, 2012, p. 16).

\section{Introdução}

Há consenso de que grande parte dos países enfrenta graves problemas econômicos e sociais. A crise iniciada em 2008 a partir do colapso da economia norte-americana causou, principalmente, desemprego acentuado e delongado - e que ainda permanece em vários países. Muitas economias vivem uma situação que parece ser crônica de anormalidade. Não são revelados indícios, seja de um colapso total, seja de uma recuperação conectada com uma expansão. O Brasil é um caso cristalino. Contudo, o biênio 2017-2018 parece ter sido bem mais

\footnotetext{
* Artigo recebido em 9 de junho de 2018 e aprovado em 22 de agosto de 2019.

${ }^{* *}$ Professor do Instituto de Economia da Universidade Federal do Rio de Janeiro (IEI / URRJ), Rio de Janeiro, RJ, Brasil. E-mail:: joaosicsu@gmail.com. ORCID: https://orcid.org/0000-0003-3997-7129.
} 
favorável para as economias avançadas e, mesmo, para o Brasil, tal como será visto ao longo do artigo.

Os Estados Unidos são uma exceção entre os países selecionados. Recuperaram suas taxas de crescimento e emprego ao longo do biênio 2017-2018. A trajetória norte-americana pode ter sido resultado da política fiscal adotada em 2008 (Economic Stimulus Act of 2008) e que se prolongou até 2010 - é provável que tal política possa ter estancado a queda livre do produto. A partir de então, a recuperação norte-americana pode ter sofrido o efeito principalmente da sua agressiva política monetária (quantitative easing) que teve início também em 2008 e que tem se prolongado - a despeito da redução de intensidade dos últimos anos. Após ter enfrentado duas recessões (em 2008 e 2009), a economia norte-americana entrou em rota de crescimento com taxas que variam entre 1,5 e 3,0\% anuais (The World Bank Data, $2018)^{1}$.

Há muitas semelhanças da situação econômica atual com aquelas dos anos 1930 e 1870. Nesses eventos, houve queda acentuada do produto, elevação drástica do desemprego e o sofrimento (para usar o termo de Krugman) que se estendeu por mais de duas décadas a partir do ano de 1873 e por mais que uma década a partir de 1929. Com uma economia basicamente agrícola nos anos 1920, o Brasil também entrou em crise. Por canais diferenciados e em anos não-coincidentes, a retração econômica daqueles anos atingiu inúmeros países.

É preciso buscar na história, na economia e nas análises comparativas, a caracterização do momento atual, que não é apenas um momento conjuntural, é um evento da história econômica. Além do diagnóstico, é preciso apontar soluções. Esses são os objetivos desse artigo.

O Brasil vive um momento histórico novo. Vive uma retração econômica de longa duração com elevado desemprego. São conhecidas as saídas, tal como destacado nas afirmações do economista, Prêmio Nobel, Paul Krugman na epígrafe.

A solução pode ser bem simples. Não seria necessário tanto sofrimento e perda de tanto tempo. Mas a vontade política tem que ser grande, tal como a do presidente norte-americano F. D. Roosevelt em 1933 quando lançou o New Deal. A solução é aparentemente cara (do ponto de vista fiscal), mas pode ser considerada barata se comparada com as perdas decorrentes da paralisia.

Embora John Maynard Keynes não tenha sido um teórico que tratou exclusivamente da economia da depressão, sua preocupação central era o funcionamento da economia capitalista, ele consumiu boa parte do seu tempo e de suas energias propondo receituários de

(1) Ao longo do artigo, faremos referências às principais economias do planeta, exceto à chinesa. Só foram consideradas em nossa análise economias que são puramente de mercado. A administração da economia chinesa é reconhecidamente estatal, centralizada e planejada, o que tem deixado esse país com autonomia de administração do seu poderoso mercado doméstico e com capacidade de manejamento do potencial de utilização do seu mercado externo. O modelo chinês, até o momento, parece ter sido eficaz para manter relações externas sem ser contaminado por elas. 
superação de processos econômicos depressivos. A solução para a superação de depressões foi oferecida pela teoria e política econômicas de Keynes e, também, pela experiência do New Deal $^{2}$. Keynes destacou que a máquina (o capitalismo) tinha tido um problema no seu partidor (os investimentos), então, não era o caso de se trocar de máquina ou de se voltar aos tempos das "carruagens barulhentas", como metaforizou Keynes.

A solução de Keynes era o mecânico (o governo) dar a partida na máquina através do investimento público em obras para reanimar todas as demais peças (os investidores e os consumidores). Essa foi e é uma solução simples, eficiente e quase sempre exequível, mas que os economistas insistem em ignorá-la ou, até mesmo, propõem a adoção de regras para impedir o seu uso.

O artigo objetiva fazer o diagnóstico da situação econômica brasileira e indicar linhas gerais de um receituário apropriado - tudo a partir das ideias e experiências de J. M. Keynes. $\mathrm{O}$ artigo está dividido em cinco seções. Na primeira, apresenta-se um esboço das principais características de uma depressão identificando suas marcas nas maiores economias capitalistas desde o evento iniciado em 2008. Na segunda, busca-se fazer uma síntese das relações entre uma recessão e uma depressão, além de mostrar as diferenças entre esses dois fenômenos. Na terceira, mostra-se que as características de uma depressão também marcam a economia brasileira da atualidade. Para tornar claro que tais características estão presentes na atualidade, mas não emergiram em graves recessões anteriores, faz-se esse cotejamento na seção 4. Na quinta seção, são descritos o diagnóstico e o receituário da Depressão dos anos 1930 feitos por Keynes com o objetivo de comparar aquele período da Grã-Bretanha (interpretações e realidade) com o momento atual da economia brasileira. Por último, são tecidas considerações finais que buscam sintetizar as principais ideias tratadas no artigo.

\section{As marcas de uma depressão}

O Brasil teve uma recessão em 2015 e outra em 2016. Não foi percebido que existem recessões que tiram a economia da sua normalidade. Não há nenhum artigo científico ou boletins de conjuntura que tenham feito essa conexão entre a recessão (dos anos de 2015 e 2016) e a entrada da economia brasileira em uma depressão. A primeira matéria de jornal que

(2) O artigo não vai explorar o New Deal aplicado por Roosevelt a partir de 1993 na economia dos Estados Unidos. Fugiríamos do escopo do artigo. Para os nossos propósitos, basta apenas destacar que o New Deal era um programa de obras públicas e de reformas. As obras públicas objetivavam estancar a queda e promover a recuperação da economia. As reformas seriam para estabelecer uma nova institucionalidade para que a economia pudesse funcionar em plena normalidade com reduzido desemprego. Keynes em carta aberta ao presidente Roosevelt, publicada no New York Times de 31 de dezembro de 1933, demonstrou sua sensibilidade política - escreveu: "você está empenhado em dupla tarefa, recuperação e reforma: a recuperação da contração e a passagem das reformas empresariais e sociais, que estão muito atrasadas. Para a primeira, velocidade e resultados rápidos são essenciais. A segunda pode ser urgente também; mas a pressa será prejudicial, e a sabedoria de propósito de longo alcance é mais necessária que a realização imediata. Será através do aumento do prestígio de sua Administração pelo sucesso na recuperação em tempo curto que você terá a força motriz para realizar uma reforma de longo alcance" (Keynes, 1982, p. 290). E em outra passagem da mesma carta, afirmou: "Se você for bem-sucedido, métodos novos e mais ousados serão tentados em todos os lugares, e podemos datar o primeiro capítulo de uma nova era econômica desde sua chegada ao cargo” (1982, p. 289). 
citou a possibilidade de o Brasil ter mergulhado dentro de uma depressão foi de 19 de maio de 2019: "O Brasil oscila entre a estagnação e a depressão, avaliam economistas" (Folha de S. Paulo, 2019) $)^{3}$. A matéria mencionou um estudo feito pela Consultoria AC Pastore \& Associados intitulado "A Depressão depois da Recessão" (é um documento curto, de sete páginas).

O referido documento afirmou tão-somente que: "Com a renda per capita mantendose por três anos $8 \%$ abaixo do pico prévio, só nos resta definir a situação como característica de uma depressão..." (Pastore et al., 2019, p. 2). E ainda dentro de tal matéria do periódico, o economista Afonso Celso Pastore afirmou: “O país está parado. Depois da recessão, não tivemos uma recuperação. A população empobreceu e não recupera a sua renda. Se isso não é sinal de depressão não sei o que é" (Folha de S. Paulo, 2019).

São recessões que tiram as economias de suas normalidades e as colocam em depressão. Por exemplo, os Estados Unidos entre 1945 e 2008 tiveram 112 meses de recessão (NBER - National Bureau of Economic Research, 2018). Entretanto, nenhum desses eventos tirou a economia norte-americana de sua normalidade. Foram recessões normais ${ }^{4}$. Somente em 2008 é que a crise recessiva levou os Estados Unidos à anormalidade - de acordo com o esboço de definição de depressão que é apresentado nessa e na próxima seção. Conforme referências a seguir, Paul Krugman, Berry Eichengreen e Alan Blinder são alguns dos economistas que consideraram que as principais economias capitalistas entraram em depressão a partir de 2008.

As depressões dos anos 1870 e 1930 tiveram algumas marcas proeminentes. São essas marcas que autorizam a classificação do evento iniciado em 2008 como também sendo uma depressão. Nessas três grandes crises as maiores economias foram atingidas. O fenômeno é internacional, houve queda acentuada do produto, elevação drástica da taxa de desemprego e existe uma prolongada insuficiência de demanda. Paul Krugman (2012) batizou a crise iniciada em 2008-2009 como sendo uma depressão por sua semelhança com os acontecimentos dos anos $1930^{5}$.

(3) A primeira versão desse artigo foi submetida à Economia e Sociedade em junho de 2018, portanto, onze meses antes da matéria da Folha de S. Paulo.

(4) As recessões normais são aquelas que quando ocorrem não retiram a economia da sua trajetória de crescimento de longo prazo. Nelas, governos e agentes reagem dentro de padrões conhecidos, isto é, os agentes reagem de forma esperada, principalmente, em relação às ações governamentais. Não ocorrem paralisias. Por outro lado, quando ocorrem recessões bruscas, acompanhadas de drásticas taxas de desemprego e agudas contrações do crédito, por algum tempo, a economia desliza da normalidade da sua trajetória de crescimento de longo prazo para a anormalidade da depressão, onde os agentes paralisam ou adiam suas decisões por desconhecerem os parâmetros da nova situação. Na normalidade, predomina a repetição de eventos e o aprendizado; na anormalidade, predomina o desconhecimento e a paralisia. As relações entre os eventos da recessão e da depressão serão exploradas na próxima seção.

(5) Eichengreen e O’Rourke (2010) afirmaram que “... globalmente estamos indo ou fazendo algo pior do que a Grande Depressão, seja a medida a produção industrial, a exportação ou a valorização de ações. Concentrar-se nos EUA faz com que se minimize esse fato alarmante. O rótulo 'Grande Recessão' pode se mostrar otimista demais. Este é um evento do tamanho da Depressão". Blinder e Zandi (2010, p.4) enfatizaram que: "Com uma clara deflação dos preços e dos salários em 2009-2011, este cenário escuro constitui uma depressão semelhante àquela da década de 1930". Contudo, houve na década de 1930, pelo menos mais uma marca, que não se repetiu de forma tão assemelhada nos anos recentes. Foi a deflação. Por exemplo, os Estados Unidos 
A insuficiência persistente de demanda é responsável por manter, por um longo tempo, o produto abaixo do produto original, isto é, aquele que o país possuía antes da crise (essa é uma característica da depressão - suas causas mais profundas, que são comportamentais, serão tratadas na próxima seção). Além disso, as taxas de desemprego permanecem altas também por um longo período. Em geral, o período de altas taxas de desemprego é mais extenso do que aquele em que o produto permanece menor que o produto original.

$\mathrm{Na}$ depressão iniciada em 2008, as quedas do produto e as elevações das taxas de desemprego foram bem menos intensas que aquelas que ocorreram nos séculos XIX e XX'. Entretanto, a longa duração do processo não mudou. A crise do século XIX foi chamada de "a Longa Depressão" e a crise do século XX de "a Grande Depressão" (não somente por conta da sua profundidade, mas também porque durou mais que uma década). ${ }^{7}$ A crise atual tem sido, para a maioria dos países, menos intensa (exceto, por exemplo, para Grécia e Espanha), mas a extensa duração tem prolongado o sofrimento de todos os atingidos, tal como nos casos dos séculos passados.

A crise global teve início com a crise financeira/econômica norte-americana de 2008. A crise se espalhou, se prolongou e se prolonga. Diversos países tiveram recessões agudas em 2008 e/ou 2009 e, depois de alguma resistência, deslizaram para dentro da depressão ${ }^{8}$. Economias da Zona do Euro somente recuperaram no ano de 2015 o PIB médio dos anos 20072008, o Japão no ano de 2013 e os Estados Unidos no ano de 2011 (The World Bank Data, 2018). Entretanto, a taxa de desemprego em muitos desses países permanece alta ou demorou alguns anos para ser reduzida para os níveis de 2007.

tiveram deflação por três anos consecutivos após a crise iniciada em 1929. Recentemente, esse país teve somente um único ano de deflação de apenas 0,36\%, em 2009. Contudo, países tais como Grécia ou Espanha tiveram quatro anos de deflação entre 2008 e 2016 (The World Bank Data, 2018).

(6) A profundidade da crise iniciada em 2008 não foi tão acentuada quanto a de 1930 porque houve reação imediata das maiores economias para impedir um mergulho em queda livre. Houve a adoção de políticas fiscais e monetárias expansionistas. As declarações das reuniões de 2009 dos líderes do G-20 foram orientações explícitas nesse sentido (ver G-20 SUMMIT, 2009). Além disso, nos tempos atuais, diversos países possuem regras institucionais que impedem que ocorram quedas profundas do PIB, como, por exemplo, benefícios previdenciários e seguro-desemprego.

(7) Nas palavras de Dobb (1983, p. 214): a “... Grande Depressão, iniciada em 1873, [foi] interrompida por surtos de recuperação em 1880 e 1888, e continuada até meados dos anos 1990...”. Por isso, é possível encontrar na literatura de forma bastante ampla a denominação de Longa Depressão para esse evento do XIX. Assim ocorreu também, por exemplo, com a economia norte-americana na Grande Depressão do século passado. Embora a economia dos Estados Unidos tenha recuperado o PIB do ano de 1929 em 1936, somente em 1943, obteve uma taxa de desemprego menor que aquela de 1929, ou seja, quatorze anos depois da quebra da Bolsa de Valores norte-americana.

(8) De forma repentina, as políticas de estancamento de queda do produto foram substituídas por políticas de austeridade. Com a crise grega já exposta, desde o fim do ano de 2009, o tom mudou na reunião de 2010 dos líderes do G-20. Apesar das maiores economias permanecerem em recessão ou estagnação, os líderes do G-20 abriram espaço para uma mudança significativa: de políticas de estímulo fiscal para políticas de austeridade. As preocupações cresceram em relação aos problemas dos orçamentos públicos. Foi abandonada a promessa de que as políticas antidepressivas seriam mantidas até que uma recuperação duradora fosse alcançada. Foi também deixada de lado a promessa de que não haveria eliminação prematura dos estímulos. Foram valorizadas políticas de ajuste fiscal chamadas de consolidação fiscal (ver G-20 Summit, 2010). Cabe ser ressaltado, no entanto, que embora a recomendação geral sobre a atividade de fiscal tenha sido seguida pela maioria dos países, os Estados Unidos, por exemplo, mantiveram fortes estímulos monetários através da conhecida política de quantitative easing o que pode ter explicado parte da sua mais rápida recuperação. 
Em algumas economias importantes da Zona do Euro, os dados disponibilizados pelo The World Bank data ainda indicam taxas de desemprego superiores àquelas de 2007. Esse é o caso, por exemplo, da Espanha, Portugal, Itália e França (tal como pode ser observado no Gráfico 1). Reino Unido e Japão demoraram alguns anos para recuperar a taxa de desemprego de 2007. Os Estados Unidos recuperaram tal taxa em 2017 (dez anos após o início da crise) ${ }^{9}$.

Segue-se aqui a visão de Paul Krugman relativamente à análise do desemprego. Ele acredita que com o fim da depressão, os níveis de emprego originais podem ser recuperados. Disse: “... parece haver forte impulso - anseio que não se limita a um lado da partição política - para encarar nossos problemas como 'estruturais' que não se resolverão facilmente, por meio de aumento de demanda" (Krugman, 2012, p. 32). Krugman contestou tais argumentos desde os anos 1930, em Ewan Clague, passando pelo ex-presidente Bill Clinton e chegando aos dias de hoje, em Charles Plosser. Krugman afirmou que os gastos da Segunda Guerra ${ }^{10}$, naquela época, e os trabalhadores muito bem qualificados e versáteis dos nossos tempos, mas que estão desempregos, comprovam que unicamente a falta de demanda é a causa do desemprego - e que o estímulo à demanda é suficiente como solução (Krugman, 2012, p. 32-34) ${ }^{11}$.

Gráfico 1

Taxas de desemprego em 2007 e 2016 em países selecionados (em \%)

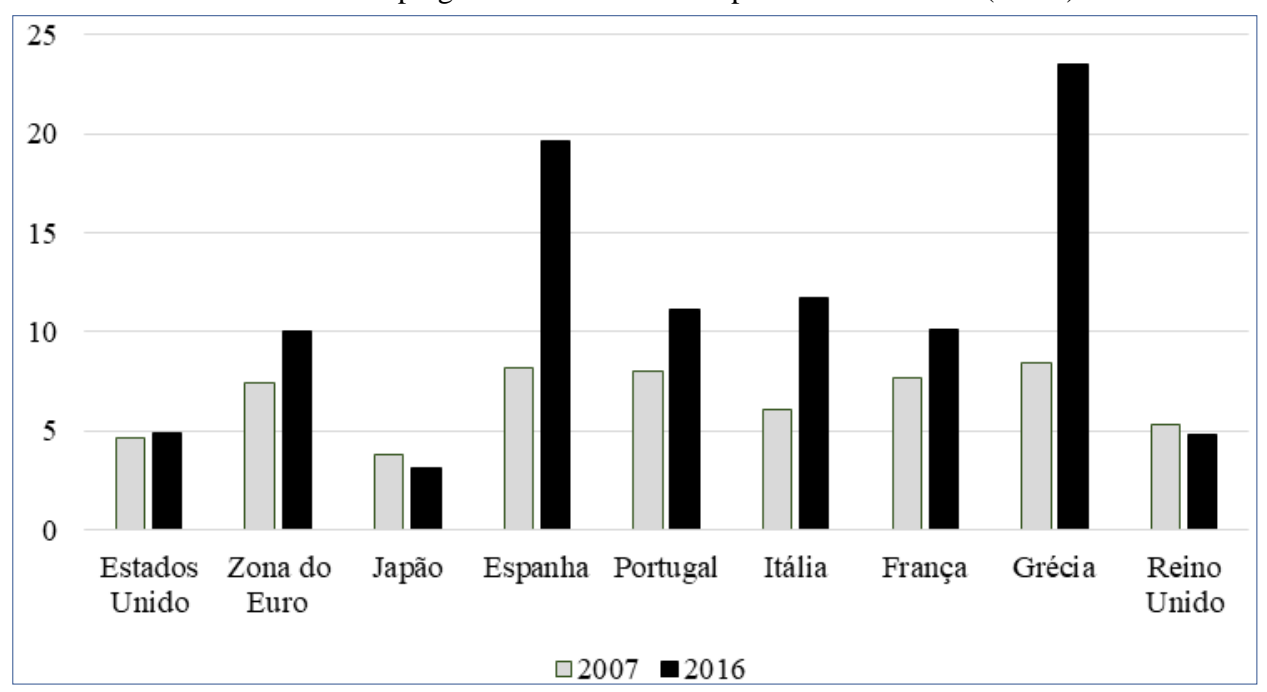

Fonte: The World Bank Data (2018).

(9) A Alemanha foi pouco afetada pela crise mundial que teve início em 2008. Esse país teve um pequeno aumento do desemprego durante o ano de 2009 (de 7,5 para 7,7\%); e, em 2016, obteve 4,1\% (The World Bank Data, 2018).

10 Para além do New Deal, a partir do final dos anos 1930, os gastos com a economia de guerra registrados na história norte-americana impulsionaram de forma definitiva a economia rumo à expansão. Para se ter uma ideia da grandeza do crescimento da economia de guerra nos Estados Unidos basta verificar que em 1929 as forças militares norte-americanas tinham 260 mil homens, ou seja, 0,5\% da força de trabalho total. Em 1944, esses números tinham saltado para 11,4 milhões de homens nas forças armadas o que equivalia a $17,3 \%$ da força de trabalho total (BLS, 1948 ).

(11) Em posição contrária à de Krugman está Ball (2014) que concluiu que a recessão dos anos 2008-2009 provocou efeitos de histerese em 23 países da $\mathrm{OCDE}$ reduzindo suas taxas potenciais de crescimento relativamente àquelas que possuíam em 2007. Contudo, Lawrence Ball destacou que a Suíça e a Austrália não incorporaram tais efeitos estruturais. 
Importantes economias do mundo ocidental permanecem em crise. Elas têm produtos menores e taxas de desemprego maiores do que tinham em 2007. Suas taxas médias de crescimento também estão bem abaixo daquelas registradas nos anos que precederam a crise.

Do que foi dito até agora, pode-se estabelecer que há três patamares de análise de variáveis que devem ser acompanhados para se ter a plena observância da superação parcial ou total de uma depressão. O primeiro patamar é a recuperação do nível de produto original. $\mathrm{O}$ segundo é a recuperação das taxas médias de crescimento do PIB que vigoravam no período pré-crise e que mantinham taxas reduzidas de desemprego. E o terceiro é a recuperação do nível de emprego original. Foi essa sequência de soluções que ocorreu no evento da Grande Depressão, particularmente nos Estados Unidos ${ }^{12}$.

Ademais, é uma marca conhecida que economias mergulhadas em uma depressão crescem ou decrescem com taxas baixas e voláteis podendo alternar taxas positivas com taxas negativas (ver a esse respeito Cardim de Carvalho, 2016, p.466). De 2007 a 2016, por exemplo, Itália e Portugal tiveram 4 anos com recessões e 5 anos com crescimento positivo. Os gráficos 2 e 3, que serão apresentados na seção 3, são outros bons exemplos dessa dinâmica do produto quando uma economia está mergulhada na depressão. Os gráficos mostram a queda profunda da economia brasileira assim como as suas oscilações (de baixa magnitude) dentro da depressão.

E, além disso, como dito, várias economias registraram em 2016 um produto menor que o produto médio de 2007-2008. A Itália teve, em 2016, um produto 6,2\% menor que o produto médio de 2007-2008 e Portugal, também em 2016, obteve um produto 3,8\% menor que o produto médio daqueles anos (The World Bank Data, 2018).

As depressões sempre tiveram início nos países mais desenvolvidos do capitalismo e se espalharam para os países não-desenvolvidos. Contudo, há causas específicas de cada economia e os canais de transmissão são diferenciados; o momento de entrada, a duração e a profundidade também não são iguais. Por exemplo, em 1929, o Brasil foi atingido pela Grande Depressão devido à queda do preço do café. O Brasil era o maior exportador mundial e os Estados Unidos era o seu maior comprador.

Em 1930, o Brasil teve uma recessão de 2,1\%, em 1931, de 3,3\%. E a partir de 1932 já entrou em rota de recuperação com elevadas taxas de crescimento econômico. Em 1932, cresceu 4,3\%, em 1933, 8,9\% e em 1934, 9,2\% (Ipea, 2018). A taxa média de crescimento do investimento (formação bruta de capital fixo) foi de $21 \%$ ao ano entre 1932 e 1934 (Ipea, 2018). Infelizmente, não existem dados sobre a taxa de desemprego para esses anos, o que certamente poderia enriquecer a análise do caso brasileiro.

(12) A economia dos Estados Unidos recuperou o PIB do ano de 1929 em 1936. Posteriormente, superou as taxas de crescimento dos anos 1920 com o superaquecimento econômico proporcionado pelos gastos com a Segunda Guerra Mundial. Contudo, somente em 1943 obteve uma taxa de desemprego menor que aquela de 1929. Em 1929, havia 1,55 milhão de desempregados; em 1933, eram 12,8 milhões; mas, em 1943, esse número baixou para 1,07 milhão (BLS, 1948). 
Apesar de ainda continuar sendo um país exportador de commodities, não foi esse um importante vetor que provocou agudas recessões e mergulhou a economia brasileira na depressão ${ }^{13}$. E nela permanece, com reduzidas oscilações - o que é, como dito, uma marca da dinâmica econômica de uma depressão.

Até o momento, foram listadas as seguintes características/marcas de uma depressão: (a) o fenômeno é internacional e atinge as principais economias, (b) queda acentuada do produto, (c) elevação drástica do desemprego, (d) prolongada insuficiência de demanda que faz com que os itens (b) e (c) não sejam mitigados por muitos anos e (d) ocorrem taxas de crescimento do produto (e também do investimento, como será visto) baixas e voláteis, positivas e negativas. Na próxima seção, serão adicionados argumentos da abordagem Marshall/Keynes que descreve comportamentos dos agentes para explicar porque economias entram em depressão e nela permanecem.

\section{Sintetizando as relações entre recessão e depressão ${ }^{14}$}

Embora esse não seja um artigo de teoria econômica, incumbe fazer uma abordagem teórica que possa auxiliar a verificação estatística das hipóteses levantadas para o caso brasileiro. Cabe um alerta: o objetivo do artigo não é estabelecer um conceito definitivo sobre o que é uma depressão, mas sim, indicar algumas de suas principais características para que possam ser cotejadas com a economia brasileira.

A distinção entre uma depressão (anormal) e uma recessão (normal) é decisiva para o entendimento do que seria a própria depressão. Embora seja enfadonho repetir, cabe lembrar que não existe ainda uma teoria da depressão na literatura econômica (ver, por exemplo, Cardim de Carvalho, 2016) - o que existe é uma vasta literatura sobre as causas da Grande Depressão. Portanto, o que é apresentado a seguir é apenas uma síntese do que foi dito sobre os eventos da depressão e da recessão e uma explicação de como esses fenômenos se relacionam entre si e se diferenciam.

Os ciclos econômicos têm amplitudes diversas, suas causas são internas ou externas. As causas internas derivam da interação entre agentes econômicos privados balizados pela institucionalidade existente (como, por exemplo, o superendividamento Ponzi-minskyano). As externas resultam de reações do setor público ou de choques (por exemplo, uma decisão governamental de contenção de gastos ou ainda um choque climático ou uma guerra). É amplamente aceito que tais flutuações cíclicas são movimentos aleatórios, mas que têm causas identificáveis.

(13) Não é objetivo do artigo descrever as causas das recessões (iniciadas em 2014) que fizeram a economia deslizar para a depressão. Elas são apenas nomeadas na próxima seção.

(14) Essa seção está baseada em Sicsú (2019, seção 4). 
Mais ainda, os ciclos não têm tido amplitude e frequência regulares (ver Fatás, $2002)^{15}$. Isso tem revelado que cada flutuação é um fenômeno isolado. Flutuações são variações do produto. E esse é o objeto que deve ser analisado dentro de cada movimento de flutuação. Nos ciclos, variações do produto sempre vem acompanhadas de variações na oferta de crédito, do investimento e no nível de desemprego - tal como serão qualificadas a seguir.

São as formas que assumem a variação do produto que vão diferir uma recessão de uma depressão. Em uma depressão, o produto é retraído de forma aguda e por um longo tempo. Na recessão, em geral, a contração não é necessariamente aguda, mas é passageira.

Nas recessões, embora haja queda do produto, maior ou menor, o desemprego tende a ser menos (ou pouco) afetado. Uma possível explicação para esse fato é que, em uma recessão, os empresários sempre atrasam as demissões devido ao custo de readmissão. E, logo que vislumbram a recuperação, não efetivam as prováveis demissões previstas anteriormente. ${ }^{16}$ Diferentemente, em uma depressão, a taxa de desemprego é imediatamente afetada de forma acentuada - e por um longo tempo. Na seção 4, será mostrado que nas mais graves recessões que o Brasil enfrentou, aquelas dos anos 1980 e 1990, embora o desemprego tenha sido afetado, sua elevação ficou muito aquém do que ocorreu em 2015 e nos anos seguintes.

Economias em depressão não são economias que repetem continuamente eventos de recessão. Muito pelo contrário, essas não foram as experiências passadas. É uma marca de depressões a ocorrência de taxas de crescimento (positivas ou negativas) baixas e voláteis. Portanto, quando ocorre uma taxa de crescimento positiva dentro de uma depressão, isso não indica necessariamente a ocorrência de uma recuperação (tal como será destacado à frente sobre o crescimento do PIB brasileiro em 2017 e 2018).

Dentro de uma depressão, nem todo crescimento pode configurar uma verdadeira recuperação. Para haver recuperação tem que haver crescimento econômico forte associado a taxas elevadas de crescimento do investimento. Fazendo referência à

(15) A visão aqui adotada é expressa em algum sentido, por exemplo, em Fatás (2002, p. 214): “[...] os ciclos de negócios não podem ser considerados desvios temporários de uma tendência. [...] O fato de existir uma forte correlação positiva entre a persistência de flutuações de curto prazo e as taxas de crescimento de longo prazo contradiz os modelos de ciclo de negócios baseados em pequenos desvios de uma solução de estado estacionário em um modelo de crescimento tipo Solow".

(16) Essa é uma especulação que é um mix de argumentos da teoria dos ciclos reais e argumentos novos-keynesianos. Durante a recessão, que se espera seja passageira (em decorrência da manutenção de comportamentos normais, tal como será visto logo em seguida), os empresários promovem um choque tecnológico negativo, ou seja, embora reduzam a produção não demitem os seus empregados. Em outras palavras, reduzem a produtividade da economia, isto é, a função de produção foi deslocada para baixo (temporariamente). Não realizam as demissões que seriam correspondentes à redução do produto porque os custos esperados de demissão/readmissão/treinamento são maiores que os custos salariais incorridos durante o evento recessivo (que é passageiro). Quando a recessão é superada, os trabalhadores voltam a produzir mais e, consequentemente, a produtividade volta a crescer. Sobre choques tecnológicos (permanentes ou temporários), ver Plosser (1989) e sobre a rigidez que mantém trabalhadores em seus empregos devido aos custos que representam, ver Blanchard e Summers (1987). 
saída da Grande Depressão, Keynes disse: “o problema da recuperação é principalmente um problema de crescimento do volume de investimentos" (Keynes, 1981, p. 480).

Uma economia fica paralisada em uma depressão caso não haja uma intervenção externa adequada de recuperação. Isso ocorre porque espontaneamente os agentes tendem a assumir comportamentos bastante defensivos (não consomem adicionalmente e não investem). Se as forças internas não se movem, caberá às forças externas realizar a recuperação (se e quando for o caso). Caberá ao Estado, elemento externo às interações dos agentes privados, reagir para promover o resgate e a recuperação da economia.

$\mathrm{Na}$ depressão, as políticas econômicas correntes perdem o efeito porque os agentes assumem parâmetros comportamentais voláteis e não-responsivos. Além disso, as reações dos agentes são inexistentes ou lentas porque tudo é desconhecido ou está em fase de reconhecimento - e também devido à perda de capacidade de reação, que é resultado do desemprego, dos prejuízos incorridos e da escassez de financiamentos em moldes adequados. Em decorrência, além de lentas, as reações são tímidas ou inexistentes já que os agentes não sabem quais são as consequências de suas decisões ou não possuem a própria capacidade de reagir.

Diferentemente, em uma recessão, meros ajustes de políticas econômicas, ou até mesmo o funcionamento normal das instituições existentes, recolocam a economia em trajetória de recuperação. Isso ocorre porque os agentes não mudaram seus parâmetros comportamentais: aceitam consumir dentro do seu padrão de normalidade e até mesmo realizam investimentos. É uma característica das recuperações pós-recessivas, um forte movimento do investimento. Pode-se especular que seria uma corrida em busca do "tempo perdido".

Esse comportamento de busca do "tempo perdido" foi identificado empiricamente, por exemplo, nas mais agudas recessões no Brasil - o que ocorreu em acordo com a ideia de Keynes de que a recuperação econômica é a recuperação do investimento (Keynes, 1981, p.480). Como será visto na seção 4, as recuperações das duas últimas graves recessões brasileiras foram marcadas por elevadas taxas de recuperação do investimento - já foi mostrado, na seção 1, que a recuperação brasileira da crise dos anos 1930 também teve como marca taxas muito elevadas de crescimento do investimento. Outro exemplo é a economia norte-americana, que ampliou em 4 pontos percentuais a participação dos investimentos no PIB de 2009 a 2019 ( $1^{\circ}$. Trim.) (CEIC, 2019). O Brasil, do ano de 2013 a 2019 (1². Trim.) reduziu tal participação em 5,5 pontos percentuais (IBGE/SCNT, 2019).

A questão fundamental é, entretanto, saber porque existem recessões que são sucedidas por uma recuperação e, portanto, são recessões normais e recessões que levam economias para as depressões. Essa não é uma conexão fácil de ser estabelecida do ponto de vista empírico, afinal, somente tivemos três episódios de depressão (1870, $1930 \mathrm{e}$ 2008 em diante). Cabe destacar que a depressão de 1870 não possui muitas estatísticas 
e grande parte das estatísticas norte-americanas foram construídas após e em virtude da depressão de 1930.

A questão precisa a ser respondida é porque, por um lado, há choques que retiram a economia da sua trajetória de crescimento e a colocam em estado de paralisia e, por outro, há choques que não são capazes de causar tal dano. A resposta foi dada por Joseph Schumpeter e Keynes. Schumpeter fez uma descrição do comportamento de variáveis e Keynes fez uma descrição de comportamentos de indivíduos que teriam implicações em uma variável-chave, o investimento. ${ }^{17}$

Schumpeter (1939, p. 925) fez uma observação sobre o prolongamento da crise recessiva. Segundo ele, quando a recessão traz por um longo período declínios erráticos e agudos da oferta de crédito e do desemprego, estaria configurada a existência de uma espiral viciosa. Segundo Schumpeter, tal espiral é a marca de uma depressão. Contudo, o economista austríaco foi além. Ele fez referência exatamente à mesma ideia utilizada por Marshall/Keynes quando disse que a existência da espiral viciosa é sinônimo de mudança de uma situação normal para uma situação anormal.

O conceito de normalidade foi amplamente utilizado por Keynes (e póskeynesianos). É uma herança de Alfred Marshall ${ }^{18}$. Nas suas palavras:

o emprego do termo normal implica a predominância de certas tendências, que se afiguram ser mais ou menos firmes e persistentes na sua atuação, sobre outras relativamente excepcionais e intermitentes. A doença é uma condição normal do homem. Mas uma longa existência transcorrida sem qualquer doença é anormal. (...) Em todos os casos, os resultados normais são os que se podem esperar... (Marshall, 1985, p. 47).

Para Marshall, os agentes econômicos saberiam como reagir em condições de normalidade, ainda que sejam em condições não desejadas. Em uma recessão normal, os eventos, em média, são repetidos, se mostram sistemáticos e têm frequência aproximadamente conhecida. Mais ainda: tendências comportamentais, algumas transformações conjunturais e mudanças de níveis de determinadas variáveis podem ser esperadas com algum grau de segurança dentro de uma recessão.

A recessão, devido à perda social que causa, é indesejada, mas é um evento normal. Os agentes econômicos estão programados para reagir em condições de normalidade (consumindo e investindo). Na depressão, por desconhecimento do ambiente e devido às graves perdas

(17) O indivíduo é importante “... não como um átomo isolado, mas como membro de determinada profissão ou grupo industrial” (Marshall, 1985, p.40). O que interessa, portanto, é o comportamento médio individual. O comportamento médio é a conduta que prevalece persistentemente diante de determinadas condições. Keynes herdou de Alfred Marshall essa abordagem tal como está indicado de forma específica na próxima nota de rodapé.

(18) Detalhes sobre a herança metodológica que Alfred Marshall deixou para Keynes e os pós-keynesianos foram apresentados e discutidos em Cardim de Carvalho (1992, cap. 2). 
incorridas, a incerteza se eleva drasticamente, os agentes, especialmente os empresários investidores, tendem à paralisia - característica crucial da anormalidade.

A motivação para a obtenção de lucros desaparece. Foi por isso que Irving Fisher definiu a depressão como sendo “... uma condição na qual o negócio se torna não-lucrativo. A depressão poderia bem ser chamada de doença dos lucros privados" (Fisher, 1932, p. 19). De forma complementar, J. Hicks destacou que "O traço característico de uma depressão econômica não é a desacumulação de capital físico [...] é a mera interrupção da acumulação; ela é suficiente, por si só, para produzir os fenômenos típicos da depressão ... “ (Hicks, 1987, p. 239).

A depressão não é um evento que tenha se repetido ao longo do tempo. Se não há repetição, não há aprendizado. Portanto, sem uma "visão de mundo" estabelecida - que é necessariamente decorrente da repetição de circunstâncias, não há aprendizado de reação predomina a paralisia. Aqui há uma correlação com as ideias de Marshall (1985, p. 36) que sugeriu que o comportamento reativo médio é elaborado a partir da existência da repetição e não dos incidentes e das particularidades. O evento da depressão é um evento que ainda pode ser considerado como particular.

Na visão de Keynes, a economia entrou em depressão nos anos 1930 porque uma variável saiu de cena, os investimentos. A questão, então, era como dar novamente a partida na máquina. Então, era preciso religar a máquina a partir do seu partidor (essas e outras metáforas foram utilizadas por Keynes tal como será visto na seção 5). O partidor eram os investimentos de capital.

Para Keynes, a recuperação somente viria, ou seja, a máquina somente seria religada, quando os investimentos voltassem - isto é, quando o estado de anormalidade (ou paralisia) fosse confrontado. Contudo, Keynes avaliava que os investidores não desejavam empréstimos para investir e banqueiros não desejam realizar tais empréstimos (Keynes, 1933, p. 145). Esses comportamentos não são normais, não são repetitivos em uma economia capitalista.

A questão então era: por que emprestadores e investidores mudaram significativamente suas "visões de mundo", que se tornaram tão divergentes? A resposta está na construção teórica elaborada por Cardim de Carvalho baseada em Keynes/Marshall e utilizada para explicar o deslizamento de uma economia para uma depressão:

Quando os choques reais são maiores que aqueles previamente julgados normais, eles ultrapassam as defesas construídas pelos agentes de tal forma que a economia não pode funcionar com sua operação regular. Como resultado, os agentes sentem a necessidade de revisar suas teorias de como as coisas funcionam "normalmente", portanto, mudam os parâmetros que definem "normalidade" (Cardim de Carvalho, 2016, p. 457).

Portanto, concluiu Cardim de Carvalho:

Dentro desse arcabouço, a depressão começa quando um choque adverso é suficientemente grande para ultrapassar as barreiras construídas pelas unidades econômicas, tornando impossível para eles manter seus padrões de comportamento e/ou 
suas teorias da economia [que estamos chamando de "visões de mundo"] (Cardim de Carvalho, 2016, p. 458).

Sendo assim, a depressão se diferencia da mera recessão não somente devido a sua permanência e profundidade de queda do produto, mas sim devido a uma mudança comportamental dos agentes econômicos que paralisam a economia em um estado de produto contraído e elevado de desemprego. A depressão ocorre quando as defesas institucionais, de política econômica e comportamentais, não foram suficientes para conter um choque negativo represando-o no nível de uma recessão ou de uma desaceleração (normais). Portanto, iniciada a depressão, não há mais como contar com as forças internas (consumidores e investidores) para religarem o magneto (termo utilizado por Keynes).

Tal abordagem de Marshall/Keynes explicaria, por exemplo, porque após a economia ter mergulhado na depressão suas taxas de crescimento (do produto e do investimento) são baixas e voláteis podendo ser positivas ou negativas. Na anormalidade da depressão, os comportamentos são defensivos. Isso explicaria a timidez de decisões de consumo, mas principalmente de investimento que, por vezes, podem ser até de contração. Além disso, as reações dos agentes podem ser diferentes e opostas porque não há uma "visão de mundo" dominante (a "teoria" da normalidade foi perdida). Dentro da depressão, pode-se encontrar eventualmente agentes otimistas e agentes pessimistas. O que há de comum, em escala predominante, são posturas defensivas. Mesmo os otimistas estão prontos para uma reversão de posição e vice-versa, ou seja, podem mudar de posição sem qualquer fundamento. As "visões de mundo" se tornam particulares e erráticas estabelecendo as condições comportamentais (principalmente dos empresários) para a volatilidade do produto.

Resumindo, para o entendimento de um esboço do que seriam as características de uma depressão é necessário relacionar comportamentos dos agentes, suas decisões e os impactos causados em variáveis tais como: investimento, crédito, produto e emprego. É preciso entender que o termo "normal", utilizado pela tradição Marshall/Keynes, relaciona comportamentos normais dos agentes econômicos com níveis normais de variáveis que se referem a agregados. Portanto, um comportamento normal (que por definição é do homem médio - empresário ou consumidor) leva ao estabelecimento do nível normal das variáveis que suas decisões influenciam. O comportamento de paralisia é, então, uma marca da anormalidade econômica. Contudo, tal anormalidade ou "condição subnormal", termo usado por Keynes, pode perdurar por muito tempo. Segundo ele, a economia poderia permanecer “... em uma condição crônica de atividade subnormal por um período considerável, sem qualquer tendência marcada, seja em direção à recuperação ou em direção ao colapso completo" (Keynes, 1973, p. 249).

O Esquema 1, a seguir, resume o esboço do conjunto de características, os comportamentos dos agentes e a dinâmica da economia saindo de um estado de normalidade e voltando a esse mesmo estágio. Pelo caminho de setas cinzas (no Esquema 1), a economia enfrentou uma recessão normal. Pelo de setas pretas, a economia foi abalroada por uma recessão que a levou para uma depressão. Na sequência, pelo caminho de setas sem cor, o governo agiu com um programa de gastos de investimento recuperando a economia para recolocá-la em condição de normalidade. 
Esquema 1

Normalidade, recessão e depressão

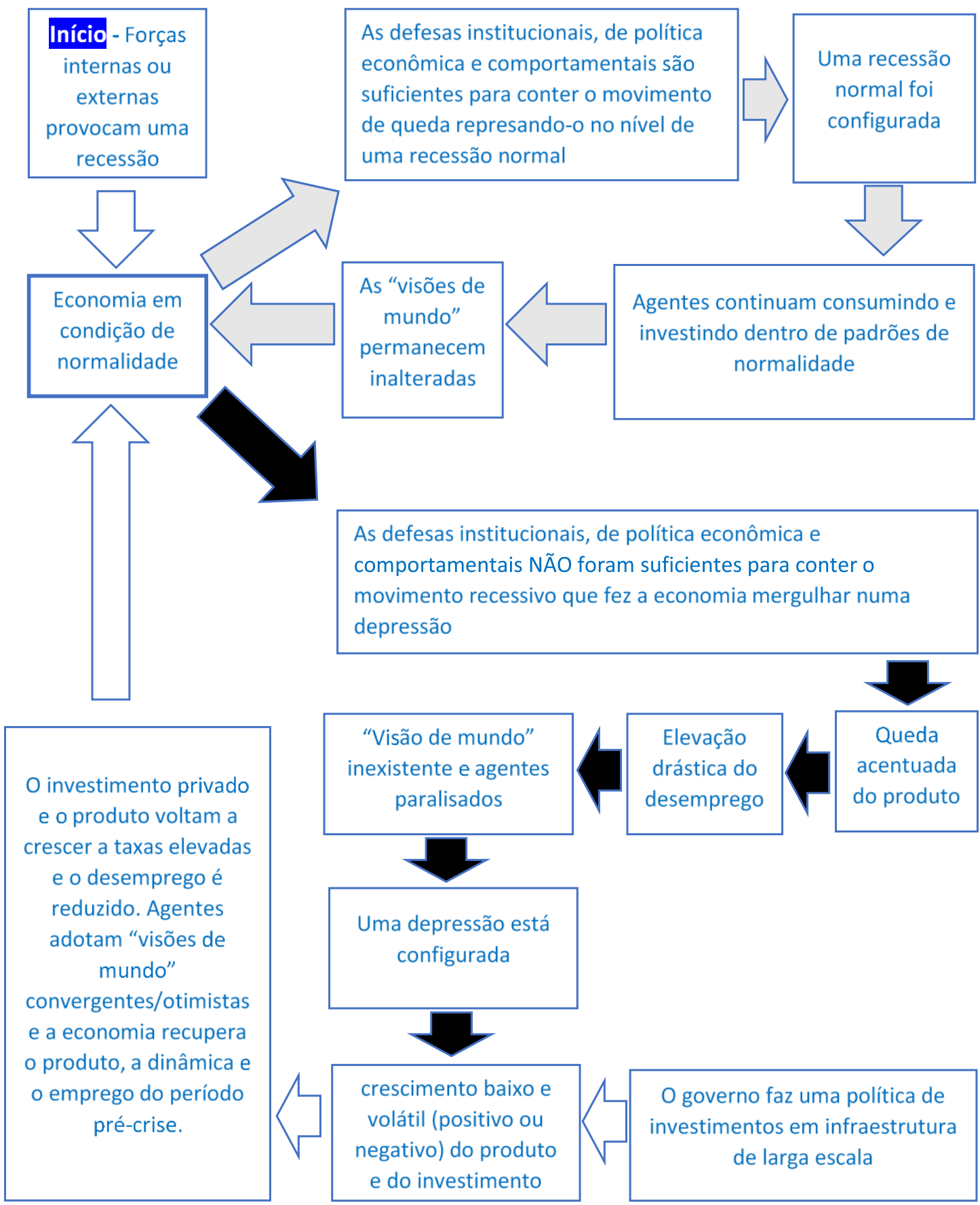




\section{Raio-X da depressão brasileira}

Até o $1^{\circ}$ trimestre de 2014, a economia brasileira estava em condições de normalidade com crescimento, embora tenha apresentado seus primeiros sinais de fraqueza ao final de 2013, quando se configurou uma tênue tendência de queda dos investimentos. Os investimentos caíram quase $2 \%$ do $3^{\circ}$ para $4^{\circ}$ trimestre daquele ano (IBGE/SCNT, 2019). Em 2014, os níveis dos investimentos e de utilização da capacidade instalada entraram em tendência descendente consistente desde o $1^{\circ}$ trimestre (IBGE/SCNT, 2019 e CNI, 2018), houve recessão no $2^{\circ}$ trimestre do ano (IBGE/SCNT, 2019) e o número de trabalhadores com carteira assinada no setor privado começou a cair a partir do $3^{\circ}$ trimestre (IBGE/PNAD Contínua, 2019).

$\mathrm{O}$ ano de 2014 era, portanto, aquele em que a economia sofria fortes pressões recessivas. Poderia ter dissolvido tais pressões e ter retornado para a mesma trajetória de crescimento dos anos anteriores com manutenção das reduzidas taxas de desemprego. A taxa média de crescimento do período 2011-2013 tinha sido de 3\% e a taxa de desemprego era de um dígito (IBGE/SCNT, 2019 e IBGE/PME, 2016). A economia brasileira poderia também, em 2014, ter sido possuída pelas forças recessivas fazendo-a deslizar para a depressão. Essa segunda opção predominou: as defesas institucionais, de política econômica e comportamentais, não foram suficientes e a economia deslizou em direção à depressão. A variável investimento considerada crucial, por Keynes, para a explicação de tal deslizamento, assumiu trajetória característica da anormalidade da depressão.

O Gráfico 2 mostra a trajetória de queda acentuada dos investimentos de 2014 até o $1^{\circ}$ trimestre de 2017. A partir de então, é possível observar no gráfico taxas de crescimento baixas e voláteis, positivas e negativas (ou seja, as barras variam pouco de tamanho e tais variações ocorrem para cima ou para baixo). Isso ocorreu e ocorre porque o comportamento empresarial é defensivo. As decisões são tímidas e, por vezes, houve retração em relação ao trimestre anterior.

Gráfico 2

Brasil - Investimento (FBCF) em número índice - 2014 a 2019, trimestral

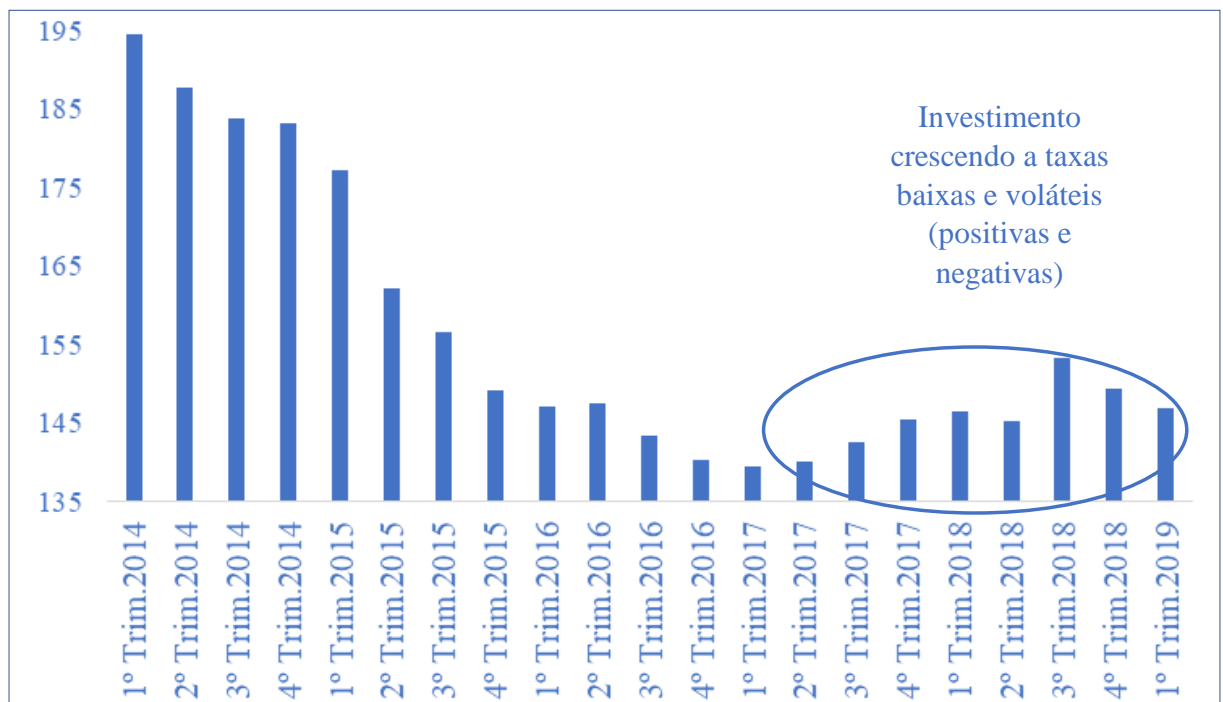

Fonte: IBGE/SCNT (2019). 
Não há uma "visão de mundo" predominante entre empresários. As "visões de mundo" são particulares e erráticas, o que explica a volatilidade da trajetória do investimento. A característica mais marcante, no entanto, é a paralisia, o que explica as baixas taxas de crescimento da variável.

A Tabela 1 sintetiza as mudanças de patamar das variáveis-chave da economia brasileira, desde o último trimestre pré-crise até o trimestre mais profundo da depressão (até o momento). O produto caiu de forma aguda, o desemprego cresceu de maneira acentuada, os investimentos despencaram, a capacidade ociosa da indústria aumentou assustadoramente e o número de trabalhadores com carteira assinada no setor privado nunca tinha sido tão baixo (desde que foi iniciada a série do IBGE em 2012). Além disso, o saldo das operações de crédito à pessoa jurídica teve retração real significativa.

Tabela 1

Variáveis selecionadas: comparação entre o último trimestre de normalidade ( $1^{\circ}$ trim. de 2014) e o trimestre de vale da depressão ( $1^{\circ}$ trim. de 2017) em número índice

\begin{tabular}{l|c|c}
\hline Variáveis em índice adimensional & $1^{\circ}$ trimestre 2014 & $1^{\circ}$ trimestre 2017 \\
\hline Nível do produto & 100 & 91,7 \\
\hline Taxa de desemprego & 100 & 190,3 \\
\hline Nível de investimentos (FBCF) & 100 & 74,7 \\
\hline Utilização da capacidade instalada da indústria* & 100 & 93,3 \\
\hline Número de trabalhadores com carteira assinada no setor privado & 100 & 91,8 \\
\hline Número de trabalhadores desempregados & 100 & 201,1 \\
\hline Saldo das operações de crédito à pessoa jurídica & $100^{* *}$ & $73,1^{* * *}$ \\
\hline
\end{tabular}

(*) último mês do trimestre, $(* *)$ dezembro de 2013 e (***) dezembro de 2017.

Fonte: Elaborado pelo autor com base nos dados do IBGE/SCNT (2019), IBGE/PNAD Contínua (2019), CNI (2018) e BCB (2018).

No Gráfico 3, pode ser observado que a partir da contração do produto no $2^{\circ}$ trimestre de 2014, a economia teve contrações e reações. O resultado é que o produto jamais voltou ao patamar original (do $1^{\mathrm{o}}$ trimestre de 2014), tal como pode ser observado no gráfico.

Ao longo de 2014, a economia apresentou um quadro generalizado de fraquezas. Nada foi feito para a promoção de um resgate ao longo daquele ano e no início de 2015. Vários vetores empurraram a economia para quedas mais agudas. Entre eles, destacam-se as políticas de austeridade adotadas pelo governo brasileiro a partir de $2015^{19}$. Em 2015 e 2016, a economia entrou em profunda recessão e se configurou o quadro de depressão que teve o seu início no $2^{\circ}$ trimestre de 2014. A economia deslizou da recessão para a depressão.

(19) Outros fatores tiveram também influência: a aguda crise política iniciada em 2014 (ver, por exemplo, Coimbra, 2014; Carlotti, 2016; El Pais, 2015 e Folha de S. Paulo, 2015), a queda dos preços (entre 2014 e 2016) das principais commodities que o país exporta (ver UNCTAD, 2016 e Itaú-BBA, 2015), operações judiciais que atingiram o PIB de 2015 e, especialmente, o emprego nas cadeias de óleo/gás e na construção civil (ver Kliass, 2017; BBC, 2015 e Valor, 2016) e, por último, mudanças de políticas econômicas ocorridas desde 2011, como, por exemplo, a redução do ritmo de crescimento dos investimentos públicos (ver Orair, 2016; Orair; Siqueira; Gobetti, 2016). 
Gráfico 3

Brasil - PIB em número índice - 2014 a 2019, trimestral

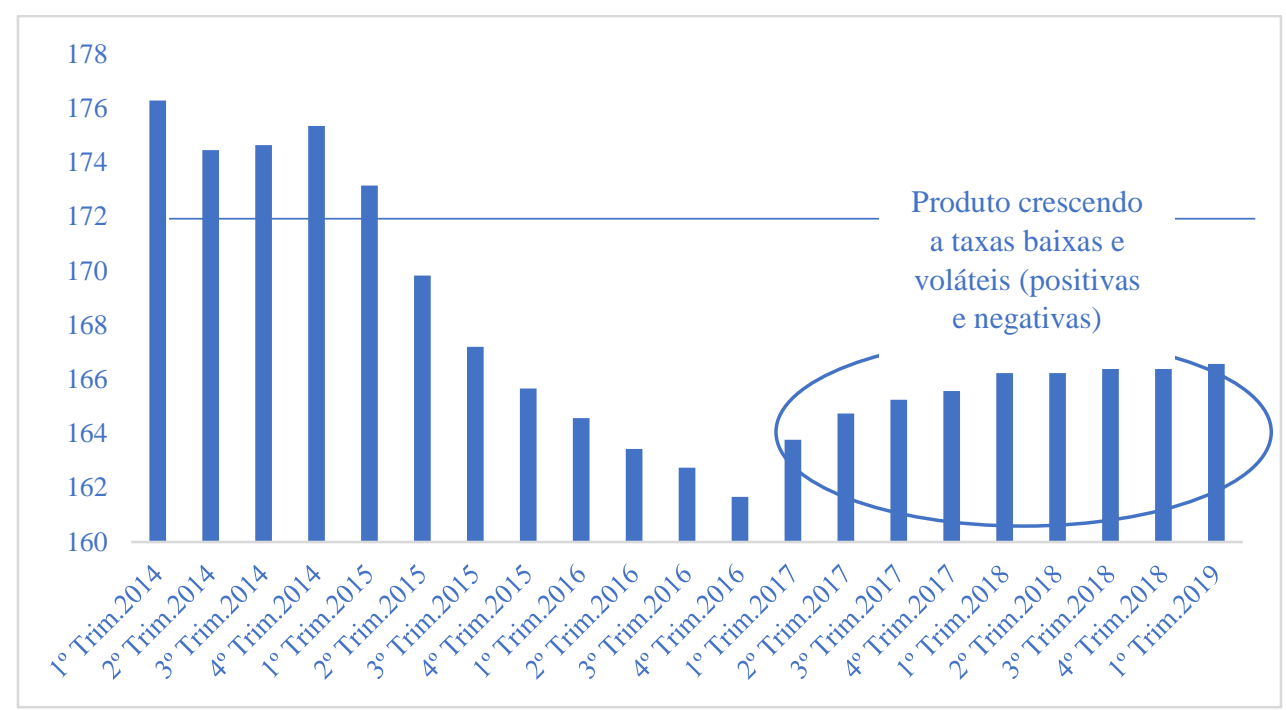

Fonte: IBGE/SCNT, 2019

Em 2015, a recessão foi de 3,8\% e em 2016 de 3,6\% (IBGE/SCNT, 2019). O número de trabalhadores desempregados aumentou de forma rápida e drástica, de 7 milhões no $1^{\circ}$ trimestre de 2014 para 14,2 milhões no $1^{\circ}$ trimestre de 2017 (IBGE/PNAD Contínua, 2019). A queda dos investimentos era ameaçadora. Os parcos investimentos realizados chegaram ao ponto de serem quase do tamanho da depreciação do estoque de capital. Assim, o estoque de capital da economia basicamente parou de crescer. ${ }^{20}$ A alma empresarial capitalista desapareceu, ou seja, desapareceu o espírito de realizar investimentos e fazer a economia crescer para gerar/obter lucros (tal como descrito por Keynes ou Schumpeter).

As fraquezas da economia brasileira apresentadas durante os anos de 2014 e 2015 foram agravadas principalmente pelas políticas econômicas adotadas pelo governo. No início de 2015, o Brasil adotou de forma explícita políticas de austeridade para supostamente combater uma crise fiscal iniciada em $2014^{21}$. Cortes de gastos públicos foram feitos em todas

(20) A taxa trimestral de crescimento (trimestre contra trimestre anterior) do estoque de capital que era $1 \%$ no período (de 2011 a 2013) anterior à crise, começou a declinar ao final de 2013. Alcançou valor muito baixo $(0,25 \%)$ no último dado disponível, que foi o $2^{\circ}$ trimestre de 2017. A taxa de crescimento, trimestre após trimestre, é decrescente e inferior a $1 \%$ desde o $1^{\circ}$ trimestre de 2014 (taxas calculadas pelo autor com base em dados do IPEA, 2018). Os valores dos últimos seis trimestres aproximaram a taxa de zero, o que significa a "mera interrupção da acumulação", a marca que seria suficiente para ser caracterizada uma depressão, tal como destacou Hicks (1987, p. 239).

(21) O diagnóstico da existência de uma crise fiscal (em 2014) é um ponto de controvérsia. Afinal, 2014 tinha sido o primeiro ano, desde o início da série divulgada pelo Banco Central, que é de 2002, que o setor público fez um déficit primário. Em 2014, o resultado primário foi deficitário em apenas $0,57 \%$ do PIB e os juros nominais atingiram um pagamento de 5,47\% do PIB (devido às elevadas taxas de juros Selic). Logo, o déficit nominal foi de 6,04\% do PIB (BCB, 2018). Ademais, tinha havido uma queda de receitas do governo de aproximadamente $2 \%$ em termos reais (RFB, 2018) devido à desaceleração econômica - o PIB cresceu 0,5\% naquele ano (IBGE/SCNT, 2019). Não existiria, então, um desequilíbrio fiscal estrutural, crescente e repetitivo. Houve um desequilíbrio conjuntural, pontual, causado pelos juros elevados e pela queda de receitas do governo. 
as áreas. Em 2015, por exemplo, os investimentos do governo central caíram, em relação ao ano anterior, 37,9\% e das estatais federais caíram 25,2\% (Orair, 2016). Paralelamente, o Banco Central do Brasil elevou a taxa de juros básica da economia (Selic). De janeiro a dezembro de 2015 , a Selic subiu de $10,5 \%$ ao ano para $14,25 \%^{22}$. Com políticas monetária e físcal contracionistas, o resultado esperado não poderia ser outro senão o mergulho da economia na depressão.

Todas as marcas das depressões dos séculos XIX, XX e XXI emergiram na economia brasileira desde meados de 2014: PIB contraído, desemprego elevado e prolongada insuficiência de demanda revelada, inclusive, pelas taxas negativas e positivas, baixas e voláteis, de crescimento do produto e do investimento por mais de quatro anos. Tanto as variáveis enfatizadas por Schumpeter para configurar a espiral viciosa (produto, emprego e crédito) quanto o comportamento empresarial e os investimentos, observados por Keynes, assumiram trajetória e níveis descritivos de uma depressão.

Em resumo, a economia brasileira está mergulhada na anormalidade, isto é, aquela situação em que o setor privado (consumidores, mas principalmente empresários) está paralisado: não faz gastos adicionais. Muito ao contrário, agentes tendem a reduzir gastos devido a expectativas pessimistas, temor e dificuldade de entendimento da situação corrente.

\section{As recessões e a depressão brasileiras}

Não há semelhança nas décadas recentes de um quadro de tanta gravidade econômica. As quedas do produto de 1981-1983 e 1990-1992 foram apenas recessões. Não configuraram uma depressão, embora as contrações do produto em termos quantitativos tenham sido semelhantes naquelas recessões e na depressão atual.

Considerando uma datação trimestral das recessões brasileiras, a contração na primeira recessão, entre o $1^{\circ}$ trimestre de 1981 e o $1^{\circ}$ de 1983 , foi de $8,5 \%$. Na segunda recessão, do $3^{\circ}$ trimestre de 1989 ao $1^{\circ}$ trimestre de 1992 , a queda foi de $7,7 \%$. Na crise em curso, do $2^{\circ}$ trimestre de 2014 ao $4^{\circ}$ trimestre de 2016, a retração foi de 8,6\% (FGV/CODACE, 2018). Contudo, é um conjunto de eventos que configuraram o quadro de depressão, não é apenas a queda do produto. Esse conjunto de eventos tirou a economia da sua normalidade.

Na recessão de 1981-1983, não houve elevação drástica do desemprego. No primeiro ano de recessão, a taxa média de desemprego subiu apenas 1,5 ponto percentual em relação ao ano anterior. Nos últimos dois anos da crise, a taxa se manteve estável com ligeira tendência de queda. Na recessão de 1990-1992, a taxa média de desemprego do primeiro ano foi de 4,6\% - apenas 1,2 ponto percentual maior que a do ano anterior. A taxa média anual atingiu o seu

(22) Essa elevação dos juros foi justificada devido ao aumento da inflação (de 10,67\% ao longo de 2015) que, por sua vez, foi causada, em grande parte, pelo aumento autorizado pelo governo dos preços da gasolina (de 20,1\%), do etanol (de 29,6\%) e da energia elétrica (de 51\%). O conjunto de preços monitorados subiu 18,1\% em 2015. O custo fiscal da elevação dos juros, em nome do controle da inflação, foi muito alto. Naquele ano, o déficit nominal do setor público foi de $10,34 \%$ do PIB, sendo o déficit primário de 1,88\% do PIB e os restantes 8,46\% ocorreram devido ao pagamento de juros da dívida pública (BCB, 2018). 
pico em 1992 com 6,1\% (IBGE/PME, 2016) ${ }^{23}$. Diferentemente, o desemprego cresceu de forma aguda na depressão atual. A taxa de desemprego no $2^{\circ}$ trimestre de 2014 foi de $6,8 \%$; saltou para $13,7 \%$ no $1^{\circ}$ trimestre de 2017 (IBGE/PNAD Contínua, 2019).

A taxa de queda dos investimentos (formação bruta de capital fixo), na recessão de 1981-1983 foi elevada, cerca de 12\% ao ano. Nos três anos posteriores, o crescimento médio anual da formação bruta de capital fixo foi de 10,5\% (Ipea, 2018). A economia voltou a crescer a taxas elevadas a partir do $2^{\circ}$ trimestre de 1983 por 17 trimestres consecutivos, ou seja, a reação não demorou muito para ocorrer.

Na recessão de 1990-1992, a taxa média de queda dos investimentos, embora menor, também foi alta: 7,4\% ao ano. Contudo, a reação à recessão foi também igualmente forte. A taxa média de crescimento dos investimentos nos anos de 1993-1995 foi de 9,3\% (Ipea, 2018). A economia voltou a crescer fortemente a partir do $2^{\circ}$ trimestre de 1992, por 12 trimestres consecutivos. Tais cenários configuram que a insuficiência de demanda não foi prolongada.

Embora a economia tenha voltado a crescer após o período 2014-2016, com crescimento de 1,1\% em 2017 e, também, em 2018, uma prolongada insuficiência de demanda permanece. O Gráfico 4 mostra as taxas de crescimento nas duas recessões e na depressão atual e faz uma comparação das taxas médias de crescimento do investimento nos três episódios. Cabe destacar que, nas recessões, os anos de recuperação apresentaram taxas extraordinárias de crescimento e estavam associadas a significativas taxas positivas de crescimento da formação bruta de capital fixo. O crescimento do biênio 2017-2018 não conformou uma trajetória de recuperação não somente porque obteve uma taxa pífia, mas principalmente porque tal taxa foi pífia pois é resultado da depressão e não uma reação à depressão.

A taxa média de crescimento do investimento do biênio 2017-2018 foi de 1,15\%, uma taxa bem inferior àquelas dos dois eventos anteriores de graves recessões. Ademais, os impulsos que ocorreram para explicar o crescimento foram temporários ${ }^{24}$. O biênio 2017-2018 foi marcado pelos suspiros que ocorrem dentro das depressões. Esse é um evento comum. É uma marca de depressões a ocorrência de taxas de crescimento (positivas ou negativas) baixas

(23) Embora a Pesquisa Mensal de Emprego (PME) do IBGE tenha sido iniciada em 1980 e tenha sido encerrada em 2012, houve descontinuidade na série devido a mudanças metodológicas. A Pesquisa foi submetida a uma revisão completa em 1982 e duas parciais, em 1988 e 1993. As comparações feitas aqui utilizaram três séries da PME: 1980-1981, 1982-1987 e 19881992. Contudo, foram tomados os devidos cuidados para que não fossem comparadas taxas de diferentes séries.

(24) Eventos episódicos explicaram o crescimento de 2017 e 2018. Segundo o IBGE, o crescimento de 2017 foi explicado basicamente pelo crescimento do agronegócio (que contribuiu com 70\% para a formação da taxa de crescimento) e o de 2018, pelo crescimento do setor de serviços (que contribuiu com 80\%). O fraco desempenho do produto pode ser ilustrado também pela variação de fatores explicativos/causas do crescimento econômico. Cabe uma menção sobre o ano de 2017: houve a apresentação de argumentos opostos que avaliaram o seu pífio crescimento. Summa, Lara e Serrano (2017) argumentaram que ocorreu uma significativa acumulação indesejada de estoques no $1^{\circ}$ trimestre que levaria, em seguida, a uma redução da produção que se refletiria negativamente no PIB. Bastos, Welle e Oliveira (2107) argumentaram que a variação do estoque de produtos industriais não tinha sido relevante e que o aumento do estoque de produtos agrícolas era uma decorrência da supersafra de soja e milho que fez aumentar a riqueza dos produtores e sua capacidade de investimento. Portanto, tal variação de estoques não seria uma explicação para o fraco desempenho do produto que estaria por vir. 
e voláteis. Portanto, o que ocorreu em 2017-2018 não foi simplesmente uma recuperação lenta, mas sim um suspiro - e não uma recuperação rumo à expansão. Dentro de uma depressão, nem todo crescimento pode configurar uma real recuperação. Para haver recuperação tem que haver crescimento econômico significativo associado a taxas elevadas de crescimento do investimento.

\section{Gráfico 4}

Brasil: taxa real de crescimento (em \%) do PIB e do investimento (taxa média) nas recessões de 1981-1983 e 1990-1992 e na depressão atual - (produto em preto, investimento em cinza)

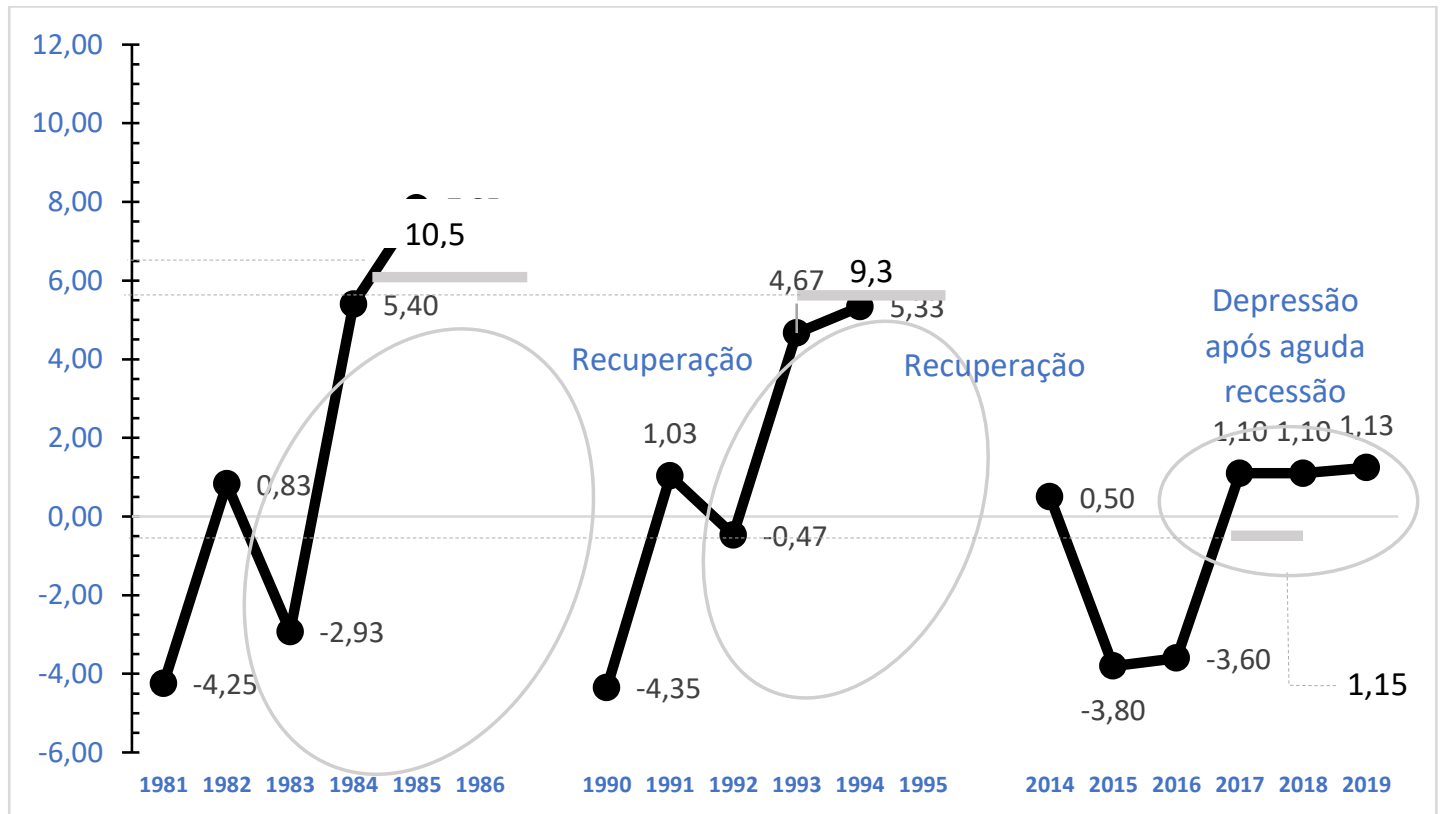

Nota: Até o momento da revisão desse artigo, as previsões do Relatório BCB/Focus para o crescimento do PIB já foram revisadas para baixo onze vezes durante o ano de 2019. A primeira previsão, de janeiro, era de crescimento de $2,6 \%$.

Fonte: Ipea (2018) para 1981 a 1995, IBGE/SCNT (2019) para 2014 a 2018 e BCB/Focus (2019) para a previsão de 2019.

O que diferenciou as duas graves recessões da depressão atual não é que nas recessões houve recuperação rápida e na depressão há uma recuperação lenta. A diferença é que não há recuperação na atual depressão. Os crescimentos recentes, como dito, são suspiros que não se conectaram com uma trajetória de expansão que estaria apoiada em taxas significativas de crescimento do investimento.

\section{Keynes manda lembranças para o Brasil}

Nessa seção estão correlacionadas ideias de Keynes referentes ao período da Grande Depressão com os eventos econômicos ocorridos no Brasil no período 2014-2019. Embora sejam dois mundos separados por cerca de noventa anos, as possibilidades de cotejamentos e 
insights são úteis para o estabelecimento de lições de políticas econômicas que visam à saída da depressão brasileira. São assuntos relevantes para o Brasil o receituário de Keynes contra o desemprego, pela superação do estado de depressão, e a sua rejeição intelectual e de política econômica aos programas de austeridade. Na próxima subseção, são apresentados o diagnóstico e o receituário de Keynes e, na seguinte, os seus argumentos contra a austeridade.

\section{i-Keynes: diagnóstico e receituário para a recuperação}

Após o estouro da bolha de riqueza da Bolsa de Nova Iorque e a internacionalização da aguda retração econômica acompanhada de drástica elevação do desemprego, Keynes fez, ao final de 1930, um interessante diagnóstico da situação utilizando criativas metáforas.

Ele reconheceu que a sociedade enfrentava “... uma das maiores catástrofes econômicas da história moderna". (Keynes 1933, p. 136) e que estava mergulhada numa "confusão colossal" cujas possibilidades de recuperação poderiam estar sendo desperdiçadas por algum tempo e já indicava "talvez por um longo tempo".

De forma semelhante, nos dias de hoje, o Brasil enfrenta a maior crise econômica de sua história. O país está mergulhado numa confusão colossal. E, desde 2014, tem desperdiçado tempo ao não realizar políticas de recuperação. Tal como apontado anteriormente, os fatores que fizeram o país deslizar das recessões ocorridas em 2015 e 2016 para a depressão ainda permanecem ativos.

Permanece em curso, por exemplo, a elaboração de propostas e programas de governo com o objetivo de promoção das políticas de austeridade que envolvem corte de gastos públicos em diversas áreas (desde investimentos a benefícios sociais). Os investimentos públicos do governo federal previstos para 2019 serão, segundo a Instituição Fiscal Independente (IFI), órgão do Senado Federal, de R $\$ 27$ bilhões, ou seja, menos que 1/3 dos investimentos realizados em 2013, que foram de R $\$ 92$ bilhões (IFI - Senado Federal, 2018).

Keynes avaliava que "a máquina tinha sido meramente travada como resultado de uma confusão" (Keynes, 1933, p.139). Estaria travada porque tinha tido um problema no seu partidor (magneto) e que, portanto, não era o caso de se pensar que haveria uma volta aos tempos das "carruagens barulhentas e que os automóveis acabar[i]am". A questão era, então, o que fazer para a máquina ser reiniciada.

Para Keynes, a recuperação ocorreria, ou seja, a máquina seria religada, quando os investimentos retornassem à economia. Contudo, avaliava que "um golfo (...) foi colocado entre as ideias dos emprestadores e dos tomadores para o propósito de investimento de capital genuinamente novo" (Keynes, 1933, p. 145). Acreditava, entretanto, que modestas reações (crescimento do produto) poderiam ocorrer dentro da depressão porque a retração tinha sido "um pouco exagerada por razões psicológicas". De forma similar, a economia brasileira deu seus primeiros sinais (de suspiros) em 2017-2018. Mas, houve uma nítida indicação que tal elevação não significava uma recuperação porque o magneto não foi reativado, isto é, o crescimento médio do investimento no referido biênio foi de apenas 1,15\%. Mas Keynes havia enfatizado: 
... não pode existir uma verdadeira recuperação, em meu julgamento, até que as ideias de emprestadores e tomadores produtivos sejam colocadas juntas novamente; em parte, emprestadores se tornando dispostos para emprestar em termos mais amigáveis e para um espaço geográfico mais amplo, e em parte, tomadores recuperando seus bons espíritos e, então, se tornando mais dispostos a tomar emprestado (Keynes, 1933, p. 145).

Keynes em 1930 identificava a situação como sendo extremamente perigosa, era uma retração profunda. Era preciso religar a máquina a partir do seu partidor, que eram os investimentos de capital. Caso contrário, “... a retração pode[ria] passar para uma depressão (...) que poderia durar por anos com perdas não esperadas de riqueza material e de estabilidade social ...” (1933, p. 146). Inicialmente, Keynes criticou aqueles que diante da grave situação sugeriam que se aumentasse a poupança privada mais que o habitual e que obras públicas fossem adiadas ou suspensas. Considerava que se isso fosse feito a situação "se torna[ria] pior e pior, um círculo vicioso" (Keynes, 1933, p. 152).

Em contexto assemelhado, o Brasil fez exatamente aquilo que Keynes sugeriu que não deveria ser feito. O governo federal reduziu, de forma contínua, os seus investimentos. Inicialmente, contribuindo para a economia entrar em recessão e, depois, na depressão. A economia entrou em um círculo vicioso de contração produto-emprego e, em seguida, encontrou um estado que se assemelha a uma paralisia no fundo do poço (ver Gráfico 3). O gráfico 5 mostra a trajetória de redução contínua do investimento do governo federal mesmo quando a economia já estava mergulhando ou já tinha alcançado um patamar mais profundo.

Gráfico 5

Investimentos públicos federais - 2013 a 2019* - Em R \$ bilhões

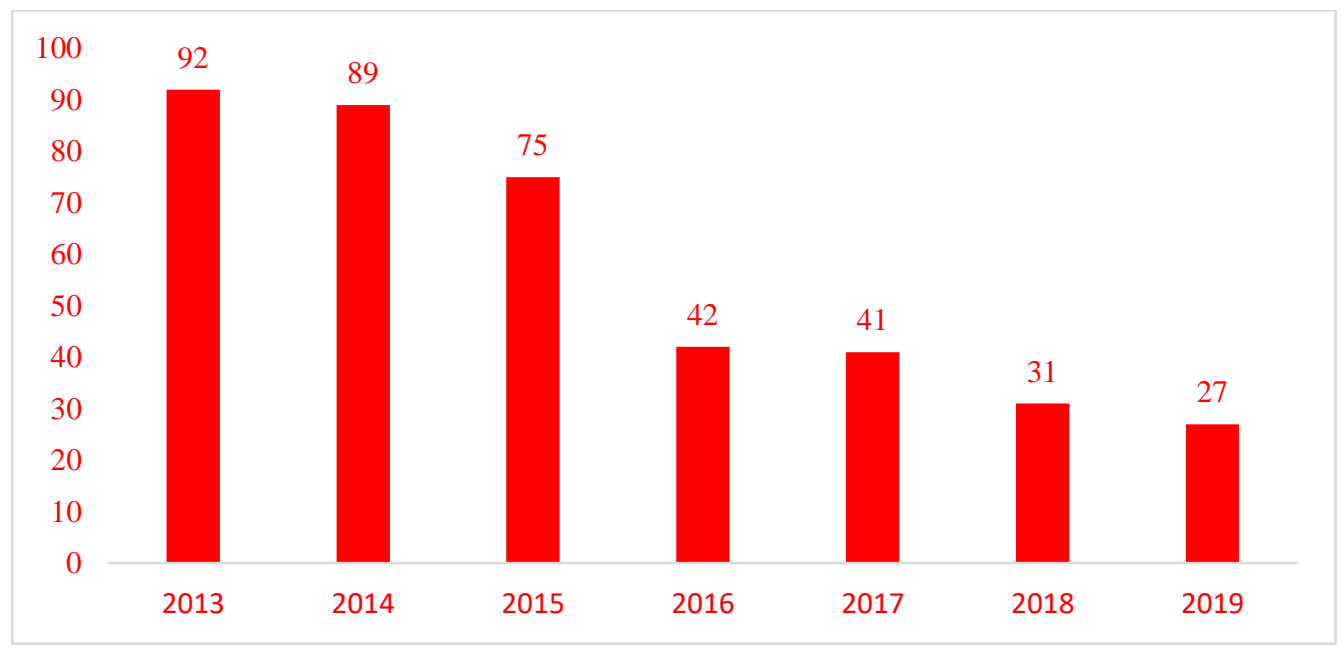

2019* = previsão IFI - Senado Federal (2018).

Fonte: IFI - Senado Federal (2018), 
Keynes argumentava que o ato de poupar transferiria trabalhadores da fabricação de bens de consumo para a produção de bens de capital, mas como já existia uma paralisação na produção de ativos de capital, então, a poupança adicional simplesmente faria aumentar o desemprego. Sentenciava: "o paciente não precisa de descanso. Ele precisa de exercícios" (Keynes, 133, p. 153).

Então, Keynes passou a enfatizar o efeito multiplicador de um corte de gastos (público ou privado) como sendo prejudicial àquela situação, mas, por outro lado, passou a valorizar e estimular o gasto em produtos domésticos para que houvesse geração de empregos em seu país. Assim, passou a fazer conclamações, por exemplo, em programas de rádio. Em janeiro de 1931, conclamou pelo rádio:

Óó... donas-de-casa patriotas, saiam amanhã cedo às ruas e vão às compras maravilhosas que estão anunciadas em todos os lugares. Vocês farão bem a vocês mesmas, nunca houve coisas tão baratas, baratas além dos seus sonhos. Façam um estoque de roupas de casa, lençóis e cobertores para satisfazer todas as suas necessidades. E tenham a alegria adicional de estarem fazendo crescer o emprego, aumentando a riqueza do país porque vocês estão colocando de pé atividades úteis, dando chance e esperança para Lancashire, Yorkshire e Belfast. (...) Façam qualquer coisa que seja imperioso para satisfazer suas necessidades e de sua casa, façam melhoramentos, construam. (Keynes, 1933, p.152) ${ }^{25}$

No mesmo programa de rádio, Keynes também destacou a necessidade de obras públicas. Keynes via nas obras públicas uma atividade que empregava muito trabalho e que melhorava a qualidade de vida. Disse ele:

... por que não demolir inteiramente o sul de Londres de Westminster a Greenwich, e fazer um bom trabalho aí - colocando para morar nessa área apropriada, próxima do trabalho, uma população muito maior que a atual, em edifícios de longe melhores com todas as facilidades da vida moderna, ainda ao mesmo tempo provendo centenas de acres de praças e avenidas, parques e espaços públicos, tendo, quando tudo finalizado, alguma coisa exuberante aos olhos, e ainda conveniente e útil para a vida humana como um monumento do nosso tempo? Isso empregaria homens? Com certeza, empregaria! (Keynes, 1933, p. 154)

Apesar de ter feito exortações ao consumo e de ter mostrado a necessidade de banqueiros e empresários tomarem decisões convergentes, Keynes reconheceu que deveria ir além. Sabia que não podia contar com os gastos privados para ativar o partidor da economia.

(25) Valem à pena a comparação. Em novembro de 2008, o Presidente Lula em rede nacional de TV e rádio discursou: "Você, meu amigo e minha amiga, não tenha medo de consumir com responsabilidade. Se você está com dívidas, procure antes equilibrar seu orçamento. Mas, se tem um dinheirinho no bolso ou recebeu o décimo terceiro, e está querendo comprar uma geladeira, um fogão ou trocar de carro, não frustre seu sonho, com medo do futuro, porque se você não comprar, o comércio não vende. E se a loja não vender, não fará novas encomendas à fábrica. E aí a fábrica produzirá menos e, a médio prazo, o seu emprego poderá estar em risco". E, em outra passagem, no mesmo programa de rádio já mencionado, Keynes explicou: “... quando você compra mercadorias você faz crescer o emprego, embora essas mercadorias tenham que ser britânicas, produzidas no país, se você deseja fazer crescer o emprego nesse país. (...) Se você compra mercadorias alguém terá que produzi-las. Se você não comprar mercadorias, as lojas não acabarão com seus estoques, elas não terão que repetir suas encomendas e alguém será posto para fora do trabalho" (Keynes, 1933, p. 152). 
Muitos indivíduos e empresas estavam endividados e com muitas dificuldades. Portanto, não fariam investimentos de capital - primeiramente, tentariam pagar suas dívidas.

No Brasil, tal como preconizado por Keynes, ocorreu que as empresas endividadas buscaram reduzir seu nível de alavancagem. Esse esforço pode ser considerado muito positivo do ponto vista micro, já que representa um front de combate à redução de exposição de balanço. Entretanto, do ponto de vista macro, tal postura representa contenção de gastos e, portanto, contribui para a retração e/ou estagnação da economia. Em 2014, o total de dívidas das empresas no Brasil em relação aos seus ativos era de 53,7\%; em 2016, essa razão foi reduzida para $45,5 \%$, tal como pode ser observado no Gráfico 6.

\section{Gráfico 6}

Evolução do endividamento (\% dos ativos) - 2013 a 2016

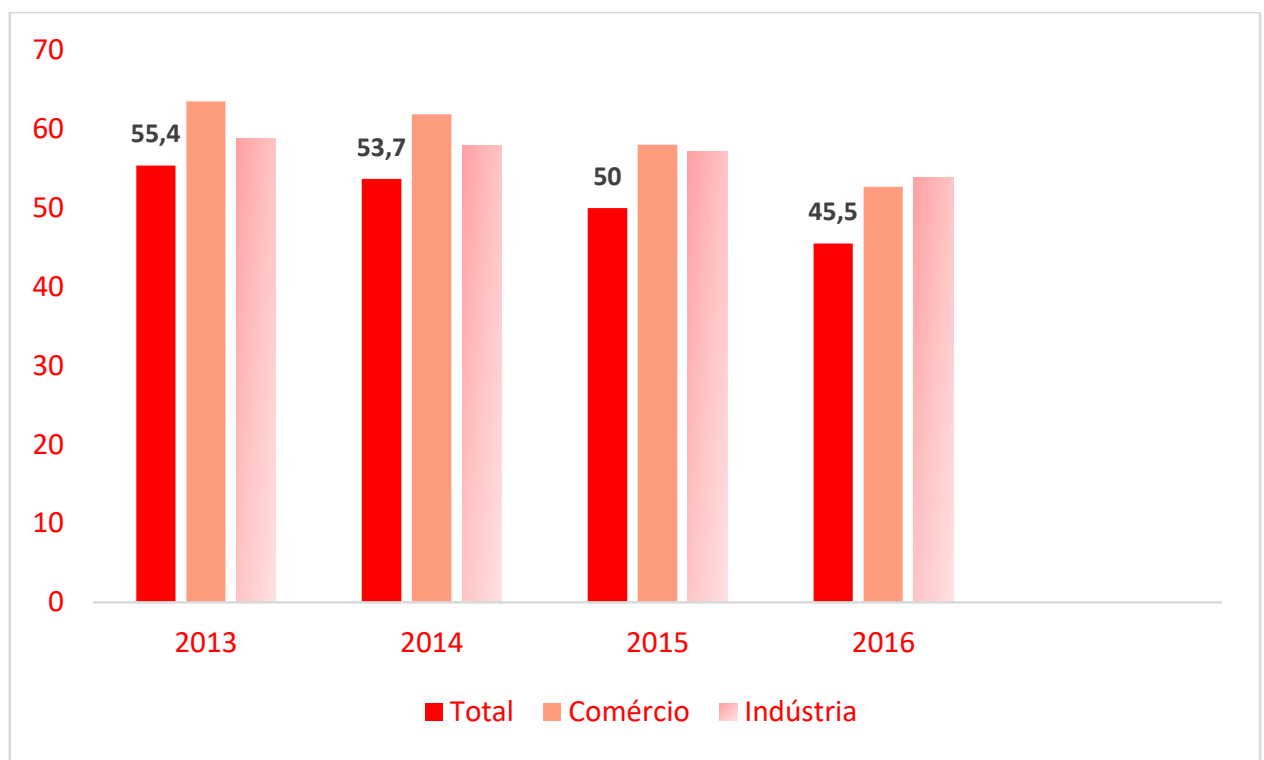

Fonte: Serasa Experian (2019).

Já que não era possível contar com as empresas que passam por dificuldades e tentavam desalavancar seus balanços, então, segundo Keynes, restaria o governo para fazer o movimento inicial:

Eu enfatizo muito a política das autoridades públicas. São elas que devem começar o movimento de partida da atividade. Você não pode esperar que os indivíduos gastem muito mais quando já estão, alguns deles, se endividando. Você não pode esperar que homens de negócio se lancem em ampliações enquanto eles estão tendo perdas. É a comunidade organizada ${ }^{26}$ que deve encontrar maneiras sábias de gastar para dar início ao movimento de partida (Keynes, 1982, p. 148).

(26) Keynes chamava as autoridades públicas de comunidade organizada (ver Keynes, 1982, p. 151). 
O Brasil não poderá contar com o receituário de Keynes. Em 2016, o Congresso Nacional aprovou a Emenda Constitucional n. 95 que proíbe que gastos públicos sejam aumentados em termos reais por vinte anos. A política de aumento de gastos públicos para fazer o movimento inicial se tornou uma impossibilidade para a economia brasileira.

A Emenda Constitucional ${ }^{\circ} 95$ foi aprovada em dezembro. Dois meses antes, o FMI havia lançado o documento "Fiscal Monitor - Debt: Use It Wisely" que estimulava que governos deveriam usar o aumento de gastos públicos para reativar economias que estavam em recessão e com processo de desalavancagem do setor privado - esse era exatamente o caso do Brasil - tal como foi mostrado nos Gráficos 3 e 6.

Diante das dificuldades e incertezas, as empresas cortaram gastos e aceleraram o pagamento de suas dívidas visando reduzir o grau de exposição de seus balanços. Mas, dessa forma, contribuíram para o aprofundamento da queda do produto. Caso houvesse espaço para um aumento de gastos públicos que pudesse auxiliar a desalavancagem privada, tal como recomendou o FMI, a queda do produto poderia ter sido amenizada (exemplos de gastos públicos sugeridos pelo FMI estão na próxima citação). Contudo, qualquer ação físcal do governo está impedida pelo teto de gastos imposto pela Emenda Constitucional $n^{\circ} 95$. Ainda que de forma diferente daquela indicada por Keynes, o FMI fez uma explícita recomendação de uso da política fiscal de gastos:

O pacote de políticas específicas dependerá, é claro, das circunstâncias do país e das reservas fiscais disponíveis. (...) que podem incluir medidas como subsídios para os credores para alongar os vencimentos, garantias, empréstimos diretos (...) embora os trade-offs sejam difíceis na atual conjuntura de espaço fiscal limitado, a inatividade provavelmente será mais cara, mesmo sob a perspectiva da sustentabilidade da dívida pública (IMF, 2016, p. ix-x) ${ }^{27}$.

Ademais, Keynes era favorável a incentivar o gasto privado para vir, na medida do possível, em paralelo ao gasto público. Assim, sugeriu que houvesse a redução dos custos das habitações, que casas e mobílias fossem modernizadas e que fosse ampliada a rede de telefonia, eletricidade e gás, para todas as residências com custo reduzido para as famílias (Keynes, 1982, p. 158-157).

Coincidentemente com a proposição habitacional de Keynes, foi lançado no Brasil em 2009, o programa Minha Casa Minha Vida (MCMV), que foi um importante instrumento de geração de empregos e melhoria da qualidade vida da população de baixa renda. Era um programa de produção de unidades habitacionais para serem vendidas com subsídios do governo federal e que tinham prestações mensais e taxas de juros adequadas para o seu público alvo. Como mostra o Gráfico 7, até 2013, o Programa teve uma geração ascendente de

(27) A recomendação do FMI foi mais ampla: “... a política fiscal não pode fazer isso sozinha; tem que ser apoiado por políticas complementares dentro de estruturas críveis. Mais especificamente, a política monetária deve permanecer acomodatícia...” (IMF, 2016, p. x). De forma contrária, o Banco Central do Brasil elevou a taxa de juros básica da economia desde 2014, quando a economia deu os primeiros sinais de enfraquecimento. Do $1^{\circ}$ trimestre de 2014 ao último de 2016, a taxa de juros básica foi aumentada de $11 \%$ para $14 \%$ a.a. (BCB, 2018). 
contratação de unidades para serem construídas. Mas, a partir de 2014, quanto mais a economia (em recessão) precisava desse instrumento mais ele era reduzido ${ }^{28}$.

Gráfico 7

Unidades contratadas pelo Programa MCMV (Posição em 31/07/2016)

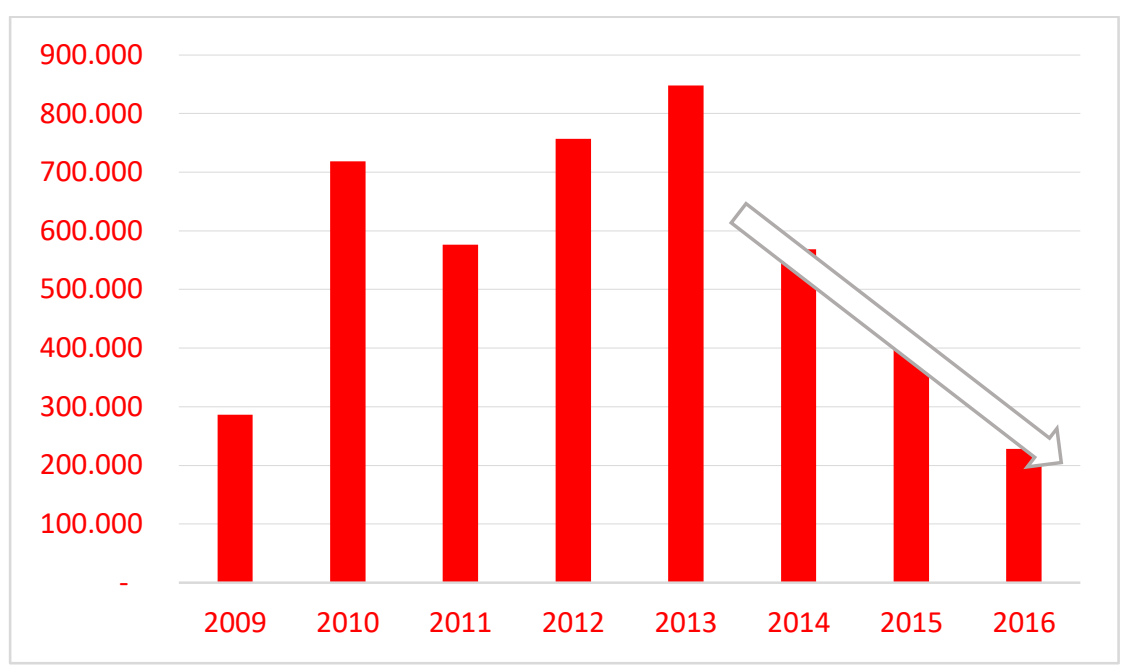

Fonte: Ministério das Cidades/SNH (2016).

Keynes ressalvou, entretanto, que esforços privados do tipo que sugeriu não funcionariam adequadamente se fossem tentados de forma isolada do gasto público que daria o movimento de partida na atividade. Seria necessário aumentar as rendas dos indivíduos e colocar novamente as poupanças para circular:

Nós devemos primeiro aumentar a renda dos indivíduos estabelecendo ampliações do capital em larga-escala que seriam capazes de fazer com que as poupanças estagnadas da comunidade circulem novamente (Keynes, 1982, p. 158).

Uma de suas conclusões mais diretas sobre a necessidade de ser dado um movimento inicial no partidor da economia e sobre a importância do gasto privado acompanhar o gasto público em obras, foi apresentada em 1932:

É dito frequentemente pelos entendidos que nós não podemos gastar mais do que ganhamos. Com certeza, isto é suficiente verdade para o indivíduo, mas isso é excessivamente enganoso se é aplicado à comunidade como um todo. Para a comunidade como um todo seria muito mais verdadeiro dizer que nós não podemos ganhar mais do que gastamos. Preços não podem crescer, produção e emprego não podem crescer, a menos que o primeiro estímulo venha do crescimento do gasto, embora nesse contexto eu inclua nos gastos, com certeza, os gastos de capital com construção de casas e coisas afins.

(28) Além disso, no ano de 2015, o preço da energia elétrica subiu $51 \%$ e o preço do botijão de gás aumentou em $22,6 \%$ (BCB, 2018). A redução da cobertura do Programa MCMV associada ao aumento do custo do uso habitacional estão em sentido oposto às recomendações (já mencionadas) de Keynes durante a Grande Depressão. 
Permita, então, nosso slogan ser: 'nós, enquanto comunidade, não podemos ganhar mais do que nós gastamos, e permita a nós considerar isso um dever cívico para estimular e promover todas as formas de gastos sensatos'. (Keynes, 1982, p.126-127)

\section{ii-Keynes: contra a austeridade - ontem e hoje}

Em fevereiro de 1931, o governo britânico formou um comitê para identificar as causas do déficit orçamentário e suas possíveis soluções. O nome oficial do fórum era Comitê sobre os Gastos Nacionais, mas ficou conhecido como Comitê May porque foi chefiado pelo servidor público especialista em finanças George May. Em julho de 1931, o Comitê May apresentou seu relatório. O relatório May de sugestões ao governo continha uma visão: procurar em qualquer situação o equilíbrio do orçamento através do corte de gastos públicos - já que o relatório diagnosticava que o governo britânico gastava mais do podia e seus gastos excessivos apenas ocupavam o lugar dos gastos privados na economia, expulsando-os.

Há uma significativa semelhança entre as proposições do relatório May e algumas das proposições contidas no documento "Um Ajuste Justo" elaborado pelo Banco Mundial com recomendações para o Brasil dos dias de hoje. O documento do Banco Mundial tem um ponto de partida: "O Governo Brasileiro gasta mais do que pode e, além disso, gasta mal" (Banco Mundial, 2017, p. 17).

O Comitê May sugeriu políticas cujo principal objetivo era buscar a diminuição das despesas públicas visando à redução dos déficits. Para tanto, segundo Keynes, o relatório sugeriu, por exemplo, “... a redução do poder de compra dos cidadãos britânicos” (Keynes, 1933, p. 157). Tal receituário atingiria também e primeiramente os funcionários públicos. Então, Keynes protestou: “...absurdo fingir que o processo pode parar professores e policiais" (Keynes, 1933, p. 157). A mesma sugestão foi apresentada para o Brasil no documento do Banco Mundial: "A massa salarial do funcionalismo público pode ser reduzida significativamente. (...) A redução dos prêmios salariais excepcionalmente altos dos servidores públicos também seria desejável de um ponto de vista de equidade" (Banco Mundial, 2017, p. 10). Em outras palavras, a redução dos salários do funcionalismo reduziria a média salarial nacional.

Segundo o relatório May, o governo britânico deveria reduzir gastos para tomar menos empréstimos. A redução de salários do funcionalismo, além de auxiliar na redução do déficit público, teria um efeito positivo sobre a redução das importações. Haveria redução de compras de bens importados: "por exemplo, se o seguro-desemprego é reduzido, os desempregados terão que apertar seus cintos e comer menos produtos importados" (Keynes, 1933, p. 158). Em relação à possiblidade de redução do seguro-desemprego, o documento do Banco Mundial sugere para o Brasil uma reforma. Assim, o "... Seguro-Desemprego poderia reduzir substancialmente o número de beneficiários e os benefícios oferecidos ..." (Banco Mundial, 2017, p. 103). 
Um achatamento da massa salarial é benéfico para a balança comercial, mas quando essa redução atinge a demanda pelos produtos locais, os empresários domésticos têm perdas, então, Keynes destacou: “...eles terão que reduzir gastos ou dispensar alguns dos seus trabalhadores, isto é, terão que seguir o exemplo do Governo..." (Keynes, 1933, p. 159). Desde 2015, os empresários brasileiros tiveram que seguir o exemplo do governo: cortaram os investimentos, reduziram a produção e demitiram milhões de trabalhadores - tal como descrito na seção 3.

Keynes concluiu que a política de corte de gastos públicos produziria exatamente o efeito inverso: no lugar de reduzir o déficit público, ele seria aumentado devido à elevação do desemprego com possível aumento do dispêndio com o seguro-desemprego e, também, em decorrência da queda nas receitas tributárias em virtude da redução dos lucros e salários (Keynes, 1933, p. 159). Ocorreram no Brasil os efeitos apontados por Keynes. O déficit público, que em 2014 foi de $6,05 \%$ do PIB, atingiu, depois das políticas de cortes gastos públicos, durante os anos de 2015 e 2016, os valores de $9 \%$ e 10,3\% do PIB, respectivamente (BCB, 2018). Em paralelo, as receitas do governo federal caíram em termos reais 5,62\%, em 2015, em relação ao ano anterior e, em 2016, caíram 2,97\%, comparativamente a 2015 (RFB, 2018).

A conclusão de Keynes é que o corte de gastos públicos faz o inverso do que faria o endividamento público para realização de obras (Keynes, 1933, p. 159). Em uma depressão, Keynes sentenciou “... todos os governos têm grandes déficits" (Keynes, 1933, p. 161). O ponto focal para ele não era a existência de déficits, mas sim onde deveriam ser utilizados os recursos tomados emprestados para cobrir os déficits públicos:

É muito melhor, de qualquer forma, que os empréstimos sejam tomados para financiar obras, se essas obras forem de alguma utilidade, que para o propósito de pagar [mais] seguro-desemprego... (Keynes, 1933, p. 161).

No caso britânico, Keynes pregava que os gastos com o seguro-desemprego poderiam ser evitados se fossem feitos gastos em obras públicas que gerariam empregos. Em outras palavras, a estratégia de recuperação seria mais eficiente com a geração de empregos - que faria aumentar as receitas do governo - do que com o pagamento de seguro-desemprego que obrigaria o governo a transformar suas receitas em gastos.

No Brasil, o crescimento do déficit público (tal como destacado anteriormente) e as consequentes dificuldades de haver espaço no orçamento para uma política de gastos anticíclica não decorreram do aumento substancial das despesas com o seguro-desemprego. Mas, principalmente, devido ao aumento do pagamento de juros referentes à dívida pública. Esse pagamento, em 2014, foi de 5,47\% do PIB e, em 2015, de 8,46\%, isto é, houve um aumento de 2,99 pontos percentuais. Tal diferença equivale a $\mathrm{R} \$ 177,4$ bilhões, ou seja, mais que o dobro do investimento do governo federal no ano de 2015 que foi de apenas $\mathrm{R} \$ 75$ bilhões (ver Gráfico 5). Esse aumento de despesas com o pagamento de juros ocorreu devido à elevação da 
taxa de juros básica da economia promovida pelo Banco Central do Brasil durante aquele ano: de janeiro a dezembro de 2015 , a taxa subiu de $10,5 \%$ ao ano para $14,25 \%$ (BCB, 2018).

Keynes concluiu suas críticas às políticas de austeridade sugeridas pelo relatório May afirmando a responsabilidade que tinha com a administração fiscal do orçamento britânico. Keynes afirmou que tinha duas políticas de administração fiscal: aquela que deveria ser utilizada durante a depressão, que priorizaria a busca incessante de espaços orçamentários para a realização de gastos com obras públicas - que dispensaria inclusive a alimentação do Fundo de Amortização ${ }^{29}$ - e outra, para ser usada

[q]uando a retração tiver acabado, quando a demanda dos empresários por novos capitais tenha recuperado o normal, o emprego esteja bom, a renda dos tributos esteja crescendo, então será o momento de restaurar o Fundo de Amortização... (Keynes, 1933, p. 162).

A conclusão sobre esse quesito em relação ao caso brasileiro é que havia um suposto espaço de utilização de políticas anticíclicas de gastos já que houve aumento dos gastos públicos e aumento do endividamento em 2015, por exemplo. Contudo, tal espaço de política fiscal é ocupado pela estrutura institucional de controle da inflação estabelecido pelo regime de metas, que é ao mesmo tempo, um instrumento que promove gastos públicos direcionados para os detentores de títulos da dívida pública - que têm uma baixa propensão a gastar. Sendo assim, houve aumento de gastos, mas que não teve efeito contra cíclico. Cabe ainda ser destacado que também no Brasil dos dias de hoje deveríamos ter duas políticas fiscais, tal como sugerido por Keynes: uma expansionista, para os momentos de recessão, e outra superavitária, para as fases de bonança.

\section{Considerações finais}

O mundo se embaralhou numa confusão colossal desde 2008. Em 2009, parecia que enfrentaria a ameaça de depressão com políticas de contenção de queda e recuperação econômica. Além disso, houve sinalização de que haveria regulação econômica, especialmente dos sistemas financeiros, para evitar novas ameaças. De tudo, somente foram colocadas em prática políticas para impedir que as economias entrassem em queda livre.

As crises de elevadas taxas de desemprego e produtos retraídos ainda não foram debeladas. As economias, com raras exceções, que já recuperaram níveis de emprego e produto do período pré-crise, crescem a taxas muito baixas, longe daquelas taxas que possuíam anteriormente à crise iniciada em 2008. O Brasil entrou atrasado na sua confusão colossal. O fez somente a partir de meados de 2014, deslizando da recessão para uma depressão.

A crise brasileira se mantém. O produto está distante do produto de 2014. A taxa de desemprego está muito elevada e não dá sinais de redução consistente. A demanda é

(29) O fundo de amortização era uma forma do governo demonstrar capacidade de pagar parte de sua dívida feita através de emissão de títulos antes que atingissem a maturidade. Ao eliminar gradualmente sua dívida ou ao demonstrar essa capacidade, o emissor de títulos aumenta as chances de atrair novos credores que são mais preocupados com o risco de inadimplência. 
persistentemente insuficiente. Os investimentos públicos desaceleraram a partir de 2011 e se reduziram a partir de 2015. Os investimentos privados seguem a mesma trajetória dos investimentos públicos.

A economia brasileira está basicamente paralisada no fundo do poço: cresce e decresce a taxas irrisórias. A instabilidade política se mantém e, por vezes, se aprofunda. A nova institucionalidade reduziu graus de liberdade dos governos por vinte anos. Há limites estreitos para os gastos públicos (devido à Emenda Constitucional n. 95/2016). As empresas estatais foram enfraquecidas. O governo não tem qualquer iniciativa para promover o crescimento e a redução do desemprego.

O setor privado é incentivado a reduzir gastos tal como o governo, por exemplo, utilizando as novas regras trabalhistas, que estão em vigor desde novembro de 2017: empresários gastam menos e trabalhadores recebem menos. Redução de gastos privados implica pressão negativa sobre o produto e o emprego. A desordem econômica e política é extraordinária. As lições deixadas pela história foram ignoradas. Keynes e seus diagnóstico e receituário foram esquecidos ou nunca foram aprendidos. $\mathrm{O}$ fundo do poço tem sido o lugar da economia brasileira. Portanto, a resposta à pergunta feita no título do artigo somente pode ser sim.

post scriptum: as citações feitas no artigo das ideias de Keynes cuja referência é o ano de 1933 são do seu livro Essays in Persuasion (primeira edição em 1931). No prefácio, Keynes afirmou que o título da obra poderia ter sido Essays in Prophecy and Persuasion porque o livro, infelizmente, era mais bem-sucedido na profecia do que na persuasão.

\section{Referências bibliográficas}

AGÊNCIA BRASIL. Brasil eleva meta de superávit primário a $R \$ 91$ bi em 2011 para acelerar queda dos juros. 2011. Disponível em: http://www.brasil.gov.br/economia-eemprego/2011/08/meta-de-superavit-primario-do-governo-central-este-ano-aumenta-paracerca-de-r-91-bilhoes. Acesso em: 15 abr. 2018.

BBC. Escândalo da Petrobras 'engoliu 2,5\% da economia em 2015', de 2 de dezembro. 2015. Disponível em: http://www.bbc.com/portuguese/noticias/2015/12/151201 lavajato ru. Acesso em: 11 abr. 2018.

BANCO MUNDIAL. Um ajuste justo: análise da eficiência e equidade do gasto público no Brasil - revisão das despesas públicas. v. I: Síntese. 2017. Disponível em: http://documents.worldbank.org/curated/en/884871511196609355/pdf/121480-REVISEDPORTUGUESE-Brazil-Public-Expenditure-Review-Overview-Portuguese-Final-revised.pdf. Acesso em: 16 fev. 2019.

BALL, L. Long-term damage from the Great Recession in OECD Countries. European Journal of Economics and Economic Policies: Intervention, v. 11, n. 2, p. 149-160, 2014. 
BASTOS, P. P. Z.; WELLE, A.; OLIVEIRA, A. L. M. Há uma recuperação sustentada da economia brasileira? O PIB de 2017 e o peso da austeridade. Campinas: Centro de Estudos de Conjuntura e Política Econômica - IE/Unicamp, jul. 2017. (Nota do Cecon, n. 2).

BCB - BANCO CENTRAL DO BRASIL. Focus: Relatório de Mercado. 2019. Disponível em: https://www.bcb.gov.br/content/focus/focus/R20190524.pdf. Acesso em: 30 maio 2019.

BCB - BANCO CENTRAL DO BRASIL. Sistema gerenciador de séries temporais. Brasília: Banco Central do Brasil, 2018. Disponível em: https://www3.bcb.gov.br/sgspub/localizarseries/localizarSeries.do?method=prepararTelaLoca lizarSeries. Acesso em: 30 maio 2018.

BLANCHARD, O. J.; SUMMERS, L. H. Hysteresis in unemployment. European Economic Review, v. 31, n. 1-2, p. 288-295, 1987.

BLS - BUREAU OF LABOR STATISTICS. Labor force, employment, and Unemployment, 1929-39: estimating methods. Washington, D.C.: Bureau of Labor Statistics, 1948. Available at: https://www.bls.gov/opub/mlr/1948/article/pdf/labor-force-employment-andunemployment-1929-39-estimating-methods.pdf. Accessed: 6 mar. 2018.

BLINDER, A.; ZANDI, M. How the Great Recession was brought to an end. 2010. Available at: https://www.economy.com/mark-zandi/documents/End-of-Great-Recession.pdf. Accessed: 9 dez. 2018.

CARLOTTI, T. Vazamentos seletivos: o conluio entre mídia e Lava Jato. Carta Maior, 8 abr. 2016. Disponível em: https://www.cartamaior.com.br/?/Editoria/Politica/Vazamentosseletivos-o-conluio-entre-midia-e-Lava-Jato/4/35911. Acesso em: 17 abr. 2018.

CARDIM DE CARVALHO, F. An outline of a theory of depression. Revista de Economia Política, v. 36, n. 3, 2016.

CARDIM DE CARVALHO, F. Mr. Keynes and the Post-Keynesians. Chetelhan: Edward Elgar, 1992.

CEIC. Accurate macro and micro data. New York, USA, 2019.

FGV - FUNDAÇÃO GETÚlIO VARGAS. CODACE - Comitê de Datação de Ciclos Econômicos. 2018. Disponível em: https://portalibre.fgv.br/data/files/F3/C1/F8/E8/A18 F66108DDC4E66CA18B7A8/Comite\%20de\%20Data_o\%20de\%20Ciclos\%20Econ_micos\% 20-\%20Comunicado\%20de\%2030 10 2017\%20 1 pdff. Acesso em: 30 maio 2018.

CNI - CONFEDERAÇÃO NACIONAL DA INDÚSTRIA. Indicadores industriais. Atividade Industrial. Brasília: Portal do Sistema Indústria, 2018. Disponível em: http://www6.sistemaindustria.org.br/gpc/externo/listaResultados.faces?codPesquisa=100.

Acesso em: 30 maio 2018. 
João Sicsú

COIMBRA, M. Aceitar os fatos. Carta Capital, 10 dez. 2014. Disponível em: https://www.cartacapital.com.br/revista/829/aceitar-os-fatos-3950.html. Acesso em: 16 abr. 2018.

DOBB, M. A evolução do capitalismo. São Paulo: Abril Cultural, 1983.

EICHENGREEN, B.; O'ROURKE. What do the new data tell us? Mar. 8, 2010. Available at: https://voxeu.org/article/tale-two-depressions-what-do-new-data-tell-us-february-2010update. Accessed: 9 dez. 2018.

EL PAÍS. Levy: ajuste fiscal explica um terço da queda do PIB. O resto é nó político. 7 set. 2015. Disponível em: https://brasil.elpais.com/brasil/2015/09/04/politica/1441399950 475629.htm. Acesso em: 11 abr. 2018.

FATÁS, A. The effects of business cycles on growth. In: LOAYZA, N.; SOTO, R. (Org.). Economic growth: sources, trends, and cycles. Santiago: Central Bank of Chile, 2002.

FOLHA DE S. PAULO. O Brasil oscila entre a estagnação e a depressão, avaliam economistas. 19 maio 2019. Edição impressa.

FOLHA DE S. PAULO. Saiba o que são as pautas-bomba nas mãos do Congresso contra o governo. 5 ago. 2015. Disponível em: http://www1.folha.uol.com.br/mercado/2015/08/1664711-saiba-o-que-sao-as-pautas-bombanas-maos-do-congresso-contra-o-governo.shtml. Acesso em: 16 ago. 2018.

FISHER, I. Booms and Depressions - some first principles. New York: Adelphi Company, 1932.

G-20 SUMMIT. Declaração dos líderes cúpula de Toronto. 2010. Disponível em: http://www.g20.utoronto.ca/2010/g20_declaration_en.pdf. Acesso em: 26 fev. 2018.

G-20 SUMMIT. Declaração dos líderes cúpula de Pittsburgh. 2009. Disponível em: http://www.g20.utoronto.ca/2009/2009communique0925-br.html. Acesso em: 26 fev. 2018.

HICKS, J. Valor e capital. São Paulo: Abril Cultural, 1987.

IBGE - INSTITUTO BRASILEIRO DE GEOGRAFIA E ESTATÍSTICA. Sistema de Contas Nacionais Trimestrais - SCNT. Rio de Janeiro: IBGE, $1^{\circ}$ trimestre de 2019. Disponível em: https://www.ibge.gov.br/estatisticas-novoportal/economicas/contas-nacionais/9300contasnacionais-trimestrais.html?=\&t=downloads. Acesso em: 30 maio 2018.

IBGE - INSTITUTO BRASILEIRO DE GEOGRAFIA E ESTATÍSTICA. Pesquisa Nacional por Amostra de Domicílios Contínua - PNAD Contínua. 3. ed. Rio de Janeiro: IBGE, 2019. Disponível em: https://www.ibge.gov.br/estatisticas-novoportal/sociais/trabalho/17270pnadcontinua.html?=\&t=series-historicas. Acesso em: 30 maio 2019. 
IBGE - INSTITUTO BRASILEIRO DE GEOGRAFIA E ESTATÍSTICA. Indicadores IBGE. Pesquisa Mensal do Emprego. Fevereiro de 2016. Rio de Janeiro, 2016. Disponível em: https://ww2.ibge.gov.br/home/estatistica/indicadores/trabalhoerendimento/pme nova/.

Acesso em: 30 maio 2018.

IFI - INSTITUIÇÃO FISCAL INDEPENDENTE - Senado Federal. Relatório de Acompanhamento Fiscal, set. 2018. Disponível em: http://www2.senado.leg.br/bdsf/bitstream/handle/id/546624/RAF20_SET2018.pdf?sequence =1. Acesso em: 30 jan. 2019.

IMF. Fiscal Monitor - Debt: use it wisely. Washington, 2016.

IPEA - INSTITUTO DE PESQUISA ECONÔMICA APLICADA. IPEADATA. 2018. Disponível em: http://www.ipeadata.gov.br. Acesso em: 30 maio 2018.

KEYNES, J. M. The Collected Writings of John Maynard Keynes. Edited by D. E. Moggridge. v. XXI: Activities 1931-1939: world and politics in Britain and America. London: Macmillan, 1982.

KEYNES, J. M. The Collected Writings of John Maynard Keynes. Edited by D. E. Moggridge. v. XX: Activities 1929-1931: rethinking employment and unemployment policies. London: Macmillan, 1981.

KEYNES, J. M. Essays in persuasion. London: Macmillan, 1933.

KLIASS, P. A Lava-Jato e a economia devastada, três anos depois. Outras Palavras, 31 mar. 2017. Disponível em: https://outraspalavras.net/outrasmidias/destaque-outras-midias/a-lavajato-e-economia-devastada-tres-anos-depois/. Aceso em: 11 abr. 2017.

KRUGMAN, P. Um basta à depressão econômica. Rio de Janeiro: Campus-Elsevier, 2012.

ITAÚ-BBA. Macro visão. 2015. Disponível em: https://www.itau.com.br/itaubba-pt/analiseseconomicas/publicacoes/macro-visao/declinio-secular-das-commodities-de-volta-a-tendencia. Acesso em: 20 maio 2018.

MARSHALL, A. Princípios de economia. São Paulo: Abril Cultural, 1985. v. 1.

ORAIR, R. Investimento público no Brasil: trajetória e relações com o regime fiscal. 2016. (Texto para Discussão Ipea, n. 2215).

ORAIR R.; SIQUEIRA, F.; GOBETTI, S. Política fiscal e ciclo econômico: uma análise baseada em multiplicadores do gasto público. XXI Prêmio Tesouro Nacional. 2016. Disponível em: $\quad$ file:///C:/Users/joaos/Downloads/2\%C2\%BA-Lugar-Rodrigo-Oct\%C3\%A1vio-Orair086\%20(1).pdf. Acesso em: 25 fev. 2018.

MINISTÉRIOS DAS CIDADES / SNH - SECRETARIA NACIONAL DE HABITAÇÃO. Acesso à Informação. $2016 . \quad$ Disponível em: http://www.consultaesic.cgu.gov.br/busca/dados/Lists/Pedido/Item/displayifs.aspx?List=0c83 
João Sicsú

9f31-47d7-4485-ab65-ab0cee9cf8fe \&ID=496914\&Web=88cc5f44-8cfe-4964-8ff4-

376b5ebb3bef. Acesso em: 30 dez. 2018.

NBER - NATIONAL BUREAU OF ECONOMIC RESEARCH (2108). US business cycle expansions and contractions. Cambridge, MA: NBER, 2010. Available at: http://admin.nber.org/cycles/ cyclesmain.html. Accessed: 02 abr. 2018.

PASTORE, A. C.; PINOTTI, M. C.; GAZZANO, M.; MAGALHÃES, P. A depressão depois da recessão. A. C. Pastore e Associados, 17 maio 2019. (Informe Especial).

PLOSSER, C. Understanding business cycles. Journal of Economic Perspectives, 3 (Summer), p. 51-77, 1989.

RFB - RECEITA FEDERAL DO BRASIL. Relatórios do Resultado da Arrecadação. Brasília: Ministério da Economia, 2018. Disponível em: http://receita.economia.gov.br/dados/receitadata/arrecadacao/relatorios-do-resultado-daarrecadacao. Acesso em: 30 maio 2018.

SERASA EXPERIAN. Indicadores Econômicos. 2019. Disponível em: https://www.serasaexperian.com.br/amplie-seus-conhecimentos/indicadores-economicos. Acesso em: 30 jan. 2019.

SUMMA, R.; LARA, F.; SERRANO, F. PIB, demanda efetiva e variação de estoques: uma visão pessimista do que já ocorreu em 2017. Brasil Debate, 2017. Disponível em: https://goo.gl/BaJ2hQ. Acesso em: 23 maio 2019.

SCHUMPETER, J. Business cycles. New York; London: McGraw-Hill Book Company, 1939.

SICSÚ, J. Brasil: é uma depressão, não foi apenas uma depressão. Revista de Economia Contemporânea, v. 23, n. 1, p. 1-41, 2019.

THE WORLD BANK. The World Bank Open Data. The World Bank Group, 2018. Available at: https://data.worldbank.org/. Acesso em: 30 maio 2018.

UNCTAD. The State of Commodity Dependence. Geneva: United Nations. 2016.

UNITED STATES DEPARTMENT OF LABOR. Labor force, employment, and unemployment, 1929-39: estimating methods. 1948. Disponível em: https://www.bls.gov/opub/mlr/1948/article/pdf/labor-force-employment-and-unemployment1929-39-estimating-methods.pdf. Acesso em: 6 mar. 2018.

VALOR. O efeito da Lava-Jato no PIB se confirmou, diz Gesner Oliveira. 15 ago. 2016. Disponível em: http://www.valor.com.br/valor-investe/casa-das-caldeiras/4672327/o-efeitoda-lava-jato-no-pib-se-confirmou-diz-gesner-olivei. Acesso em: 11 abr. 2018. 